\title{
Early 1960s Excavations at the Sam Kaufman Site (41RR16), Red River County, Texas
}

Timothy K. Perttula

Heritage Research Center, Stephen F. Austin State University

Mark Walters

Heritage Research Center, Stephen F. Austin State University

Bo Nelson

Heritage Research Center, Stephen F. Austin State University

Follow this and additional works at: https://scholarworks.sfasu.edu/ita

Part of the American Material Culture Commons, Archaeological Anthropology Commons, Environmental Studies Commons, Other American Studies Commons, Other Arts and Humanities Commons, Other History of Art, Architecture, and Archaeology Commons, and the United States History Commons

Tell us how this article helped you.

This Article is brought to you for free and open access by the Center for Regional Heritage Research at SFA ScholarWorks. It has been accepted for inclusion in Index of Texas Archaeology: Open Access Gray Literature from the Lone Star State by an authorized editor of SFA ScholarWorks. For more information, please contact cdsscholarworks@sfasu.edu. 


\section{Early 1960s Excavations at the Sam Kaufman Site (41RR16), Red River County, Texas}

\section{Creative Commons License}

\section{(c) (1) (9)}

This work is licensed under a Creative Commons Attribution-NonCommercial 4.0 International License 


\title{
Early 1960s Excavations at the Sam Kaufman Site (41RR16), Red River County, Texas
}

\author{
Timothy K. Perttula, Mark Walters, and Bo Nelson
}

\section{INTRODUCTION}

The Sam Kaufman site (41RR16, also known as the Arnold Roitsch site for a time) is a well-known Caddo Indian village along Mound Prairie and the Red River in Red River County, Texas. There have been a number of reported archaeological investigations (Banks and Banks 2002; Bruseth 1998; Bruseth and Perttula 1991; Harris 1951, 1953; Harris and Wilson 1956; Harris et al. 1954; Perino 1983; Perkins 1955; Perttula 2008a; Perttula et al. 2001; Skinner et al. 1969), as well as bioarchaeological (Butler 1969; Derrick et al. 2008; Lovcland 1980, 1994; Loveland and Bass 1983a, 1983b) studies, at the site, and at other nearby sitcs (Hampton and Moore 1936; Kenmotsu 2001, 2006; Perttula 2008b; Prikryl 2008; Reese 2001) since the $1930 \mathrm{~s}$.

This article reports on previously unknown investigations conducted by Buddy Calvin Jones in December 1961 through January 1962 at the Sam Kaufman site (Figure 1). His notes on the work - which primarily consist of burial plan drawings and a map or two-have recently been provided to the Gregg County Historical Museum (GCHM). Some of the collection of archaeological materials from the site have also been located at the GCHM, and in May 2011, we had the opportunity to document those materials (all ceramic vessels). Other vessels from the Jones investigations, but not in the GCHM collections, at the Sam Kaufman site are discussed in Perttula (2006:133-135) and Perttula et al. (2009:222-227).

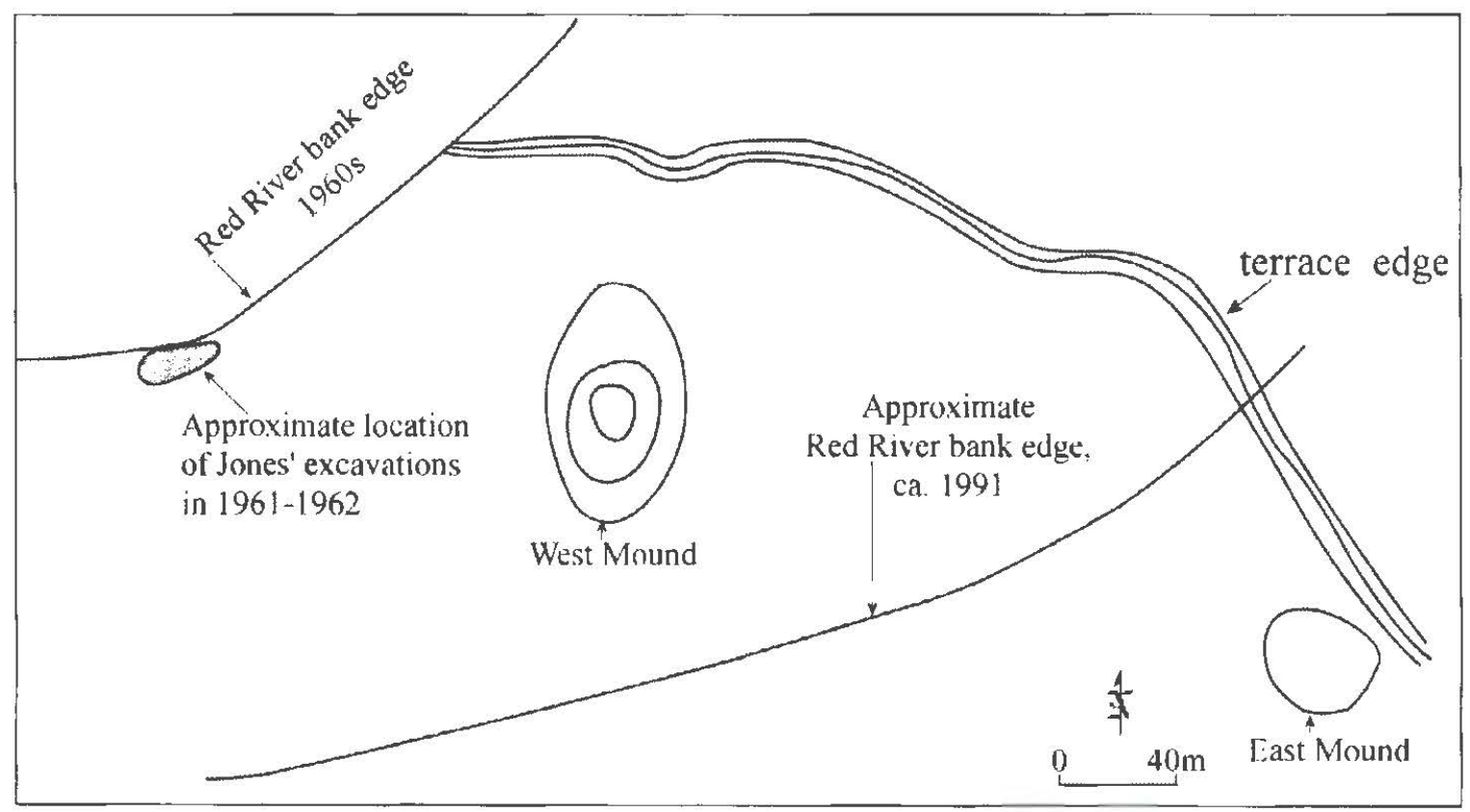

Figure 1. Location of early 1960s excavations by Buddy Calvin Jones at the Sam Kaufman site (4IRR 16), in Perttula, Walters, and Nelson article (Figure 1). 


\section{EXCAVATIONS}

The excavations completcd by Buddy Jones at the Sam Kaufman site in the winter of 1961-1962 consisted of the excavation of eight burial features (Burials No. 1-8) near the eroding bank of the Red River (Figure 2). This prehistoric Caddo cemetery area was about $120 \mathrm{~m}$ due west of the West Mound at the site (see Figure 1). Thesc areas have long been eroded away by the Red River; the West Mound was washed away in the flood of 1990 (Pertluta 2008a:313).

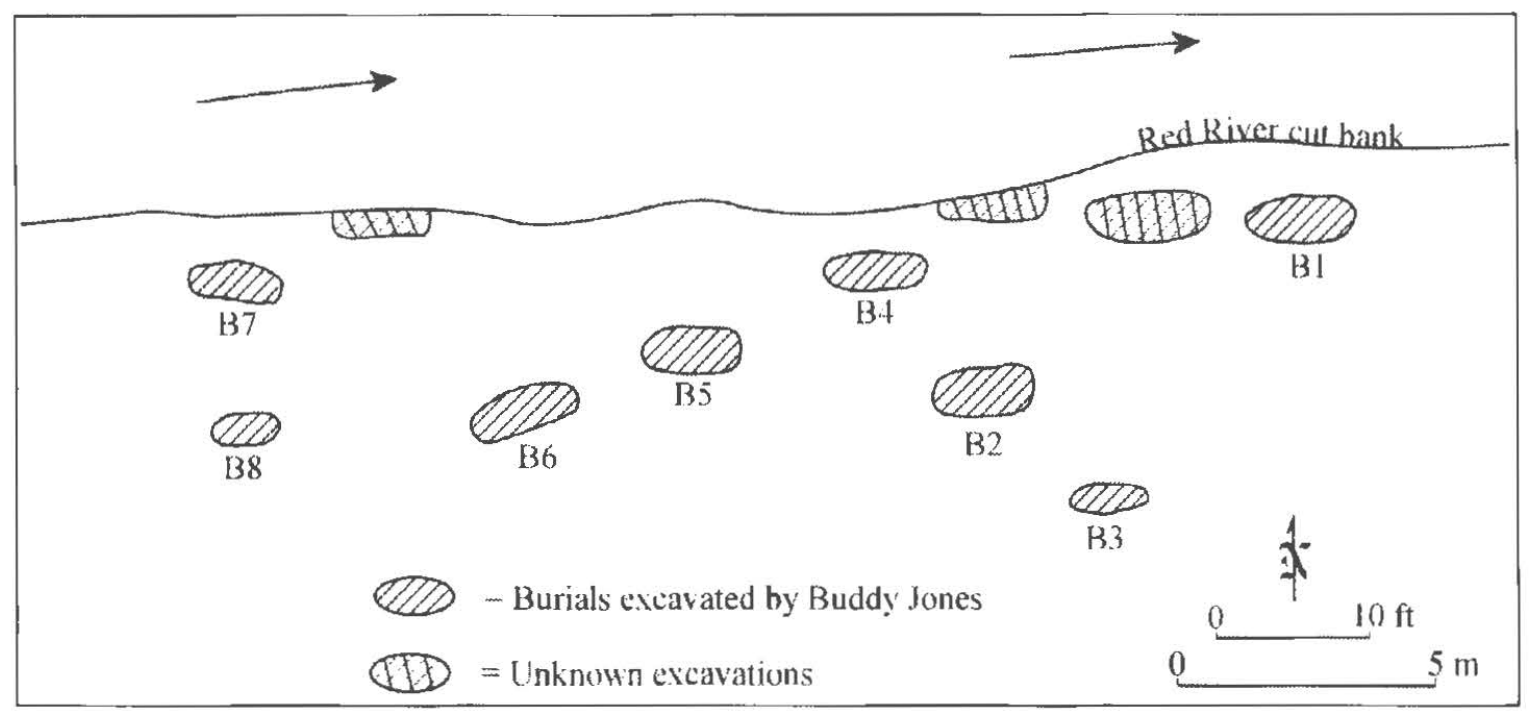

Figure 2. Plan of the excavations along the Red River Bank.

The burial features were spaced out over an area of approximately $80 \mathrm{ft}$. east-west and $24 \mathrm{ft}$. nurthsouth (ca. $24.4 \times 7.3 \mathrm{~m}$, or $178 \mathrm{~m}^{2}$ ). Three of the burials (No. 1, No. 4, and No. 7) were within 2-3 ft. of the Red River cut bank.

\section{BURIAL FEATURES}

In Jones' notes, he provides detailed plan map of six of the eight burials (Nos. 2-4 and 6-8), and very small sketch maps of all the burials (see Figure 2). From these, it is apparent that eight of the nine burials (i.e., Burial No. 2 had two individuals placed in it) were placed in graves that were oriented cast-west, with the face of the deceased facing west towards the Caddo 's House of the Dead in the Sky. The burials were placed in an extended supine position. Burial 6 was oriented northeast-southwest, with the head of the deccased pointing more towards the southwest. The majority of the burials from a terrace edge cemetery southcast of the East Mound were also oriented southwest-northeast (Perttula 2008a:Figures 5 and 37).

Burial 1 was placed in a pit approximately $7.2 \mathrm{ft}$ in length and $3 \mathrm{ft}$. in width (see Figurc 2); the burial pit size suggests this was an adult individual. The small sketch map that Jones prepared suggests that eight ceramic vessels were placed with the burial, four on each side of the body, beginning next to the head and extending to the waist area.

Five of the vessels are described by Perttula et al. (2009:222-226 and Figures 203-206). They are primarily shell-tempered. The include a large Nash Neck Banded jar, a small incised-punctated jar of undetermined type, an engraved jar of undetermined type with four lug handles, a hubcap style Simms Engraved, var. Darco carinated bowl, and a large plain grog-tempered carinated bowl. It is possible that a 
Keno Trailed, var. Phillips bowl was among the vessels Jones recovered in Burial 1, along with a spoolnecked bottle with an intertwined scroll motif on the body (Perttula 2006:134).

Burial No. 2 had two adult individuals placed in it, along with six vessels (Figure 3 ). The first burial (No. 1) was laid in the burial pit (the pit measured $6.5 \mathrm{ft} \times 3.5 \mathrm{ft}$.) first, in an extended position and the head facing west, and five of the six vessels were clustered by the left side of the head and left and right shoulder. Individual No. 2 was placed in the grave next to Individual No. 1, but the individual's legs rested atop those of Individual No. 1, and the head faced almost due south. Individual No. 2 had a portion of a single vessel (a wide-mouthed bottle) placed in front of its face.

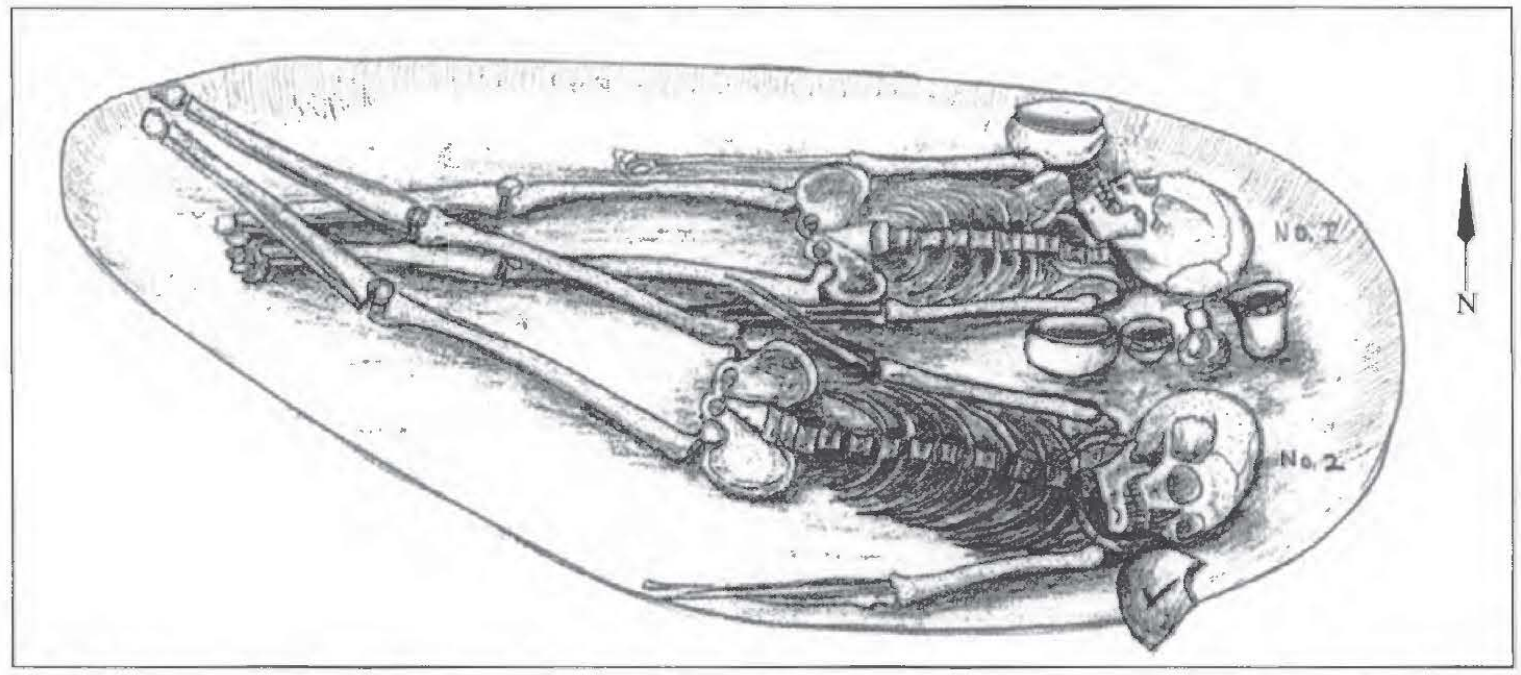

Figure 3. Plan map of Burial No. 2.

From the burial plan map, the vessels with Burial No. 2, Individual No. 1 included a Hudson Engraved bottle, two plain bowls, a Simms Engraved bowl, and an Avery Engraved deep bowl. The Simms Engraved, var. Darco carinated bowl has been previously documented by Perttula et al. (2009:226-227 and Figure 207).

Burial No. 3 had also been buried with their face oriented to the south (Figure 4). The burial pit was approximately $6.5 \mathrm{ft}$. in length and $3.5 \mathrm{ft}$. in width. The five burial vessels were placed around the left side of the head, at the left shoulder, and by the left leg. These vessels included a Hudson Engraved bottle, a Hudson Engraved jar (see below), two Nash Neck Banded jars, and an Avery Engraved deep bowl.

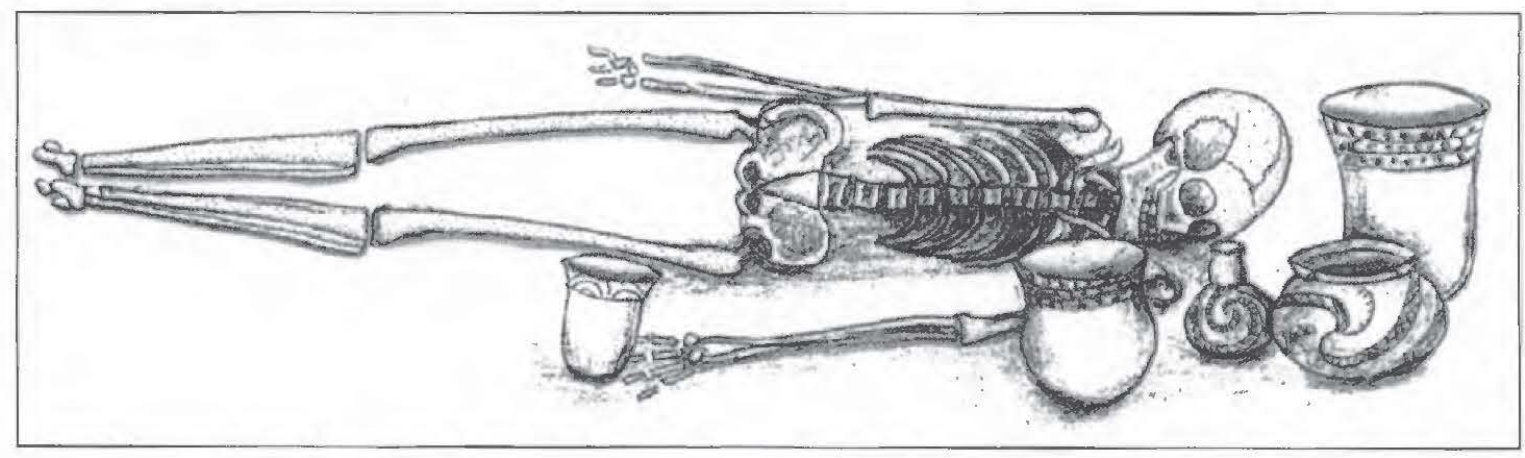

Figure 4. Plan map of Burial No. 3. 
Burial No. 4 is an adult Caddo, placed in a pit that was $6.8 \mathrm{ft}$. in length and $3.25 \mathrm{ft}$. in width (Figure 5). The burial pit had been dug to $2.5 \mathrm{ft}$. bs. A small amount of wood charcoal was noted by Jones from the floor of the grave pit. This charcoal may represent the remnants of a fire constructed on the pit floor as part of the ceremonies conducted during the course of the mortuary rituals (cf. Gonzalez 2005).

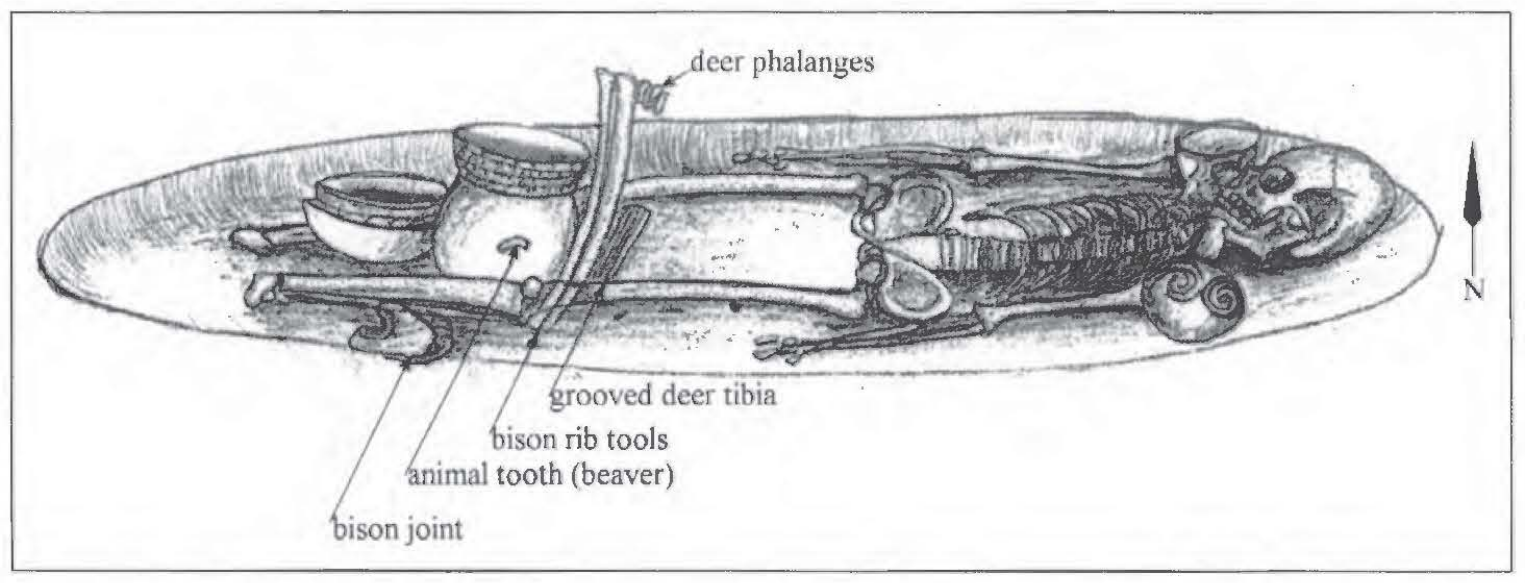

Figure 5. Plan map of Burial No. 4.

A number of associated grave goods were placed in the burial pit to accompany the deceased on their journey. These include four ceramic vessels and five animal hones, several being tools. Two of the vessels are by the head of the deceased, a possible Keno Trailed, var. Phillips bowl by the right side, and a Keno Trailed bottle by the left shoulder. The other two vessels, a Nash Neck Banded jar, and a Simms Engraved shouldered bowl, were placed between the lower legs (see Figure 5). The animal bones included deer phalanges, a deer tibia tool, probably a beamer, and two bison rib tools, as well as part of a bison leg bone and a polished beaver tooth (see Figure 5).

Burial No. 5 was also that of an adult individual, based on the pit size of $6.5 \mathrm{ft}$. in length and $3.5 \mathrm{ft}$. in width (see Figure 2). The tiny sketch map of Burial 5 indicates that it had four associated ceramic vessels, three by the head and shoulders, and a fourth vessel by the lower left leg. One of the vessels was a plain shell-tempered bottle (see below) presumably placed by the head.

Burial No. 6 was placed in a burial pit that was $6.5 \mathrm{ft}$. in length and a narrow $2.2 \mathrm{ft}$. in width (Figure 6). It was accompanied by four associated ceramic vessels and a deer mandible placed by the left shoulder. The vessels depicted on Figure 6 include a large Nash Neck Banded jar (see also Perttula 2006:Figure 310 ) by the left side of the head, an incised jar of unknown type by and above the right side of the head, a Keno Trailed bottle (see Perttula 2006:Figure 309) resting on the right arm, and an engraved carinated bowl by the left elbow.

The Caddo adult buried in Burial No. 7 was placed in the grave in an east-west extended supine position, but the head was facing to the south (Figure 7), as was also the case for Individual No. 2 in Burial No. 1 and Burial No. 3. The Burial No. 7 pit is approximately $6.3 \mathrm{ft}$. in length and $2.5 \mathrm{ft}$. in width; the pit was excavated to $2 \mathrm{ft}$. bs.

Two ceramic vessels were apparently placed with the deceased in Burial No. 7 (see below), although there are sherds from a Hudson Engraved bottle labeled as coming from Burial No. 7 in the GCHM collections from the site; if this is the case, there is no information available on where it was placed in the grave. A Simms Engraved shouldered bowl was by the left arm, while a large Nash Neck Banded jar had been placed by the upper right leg. 


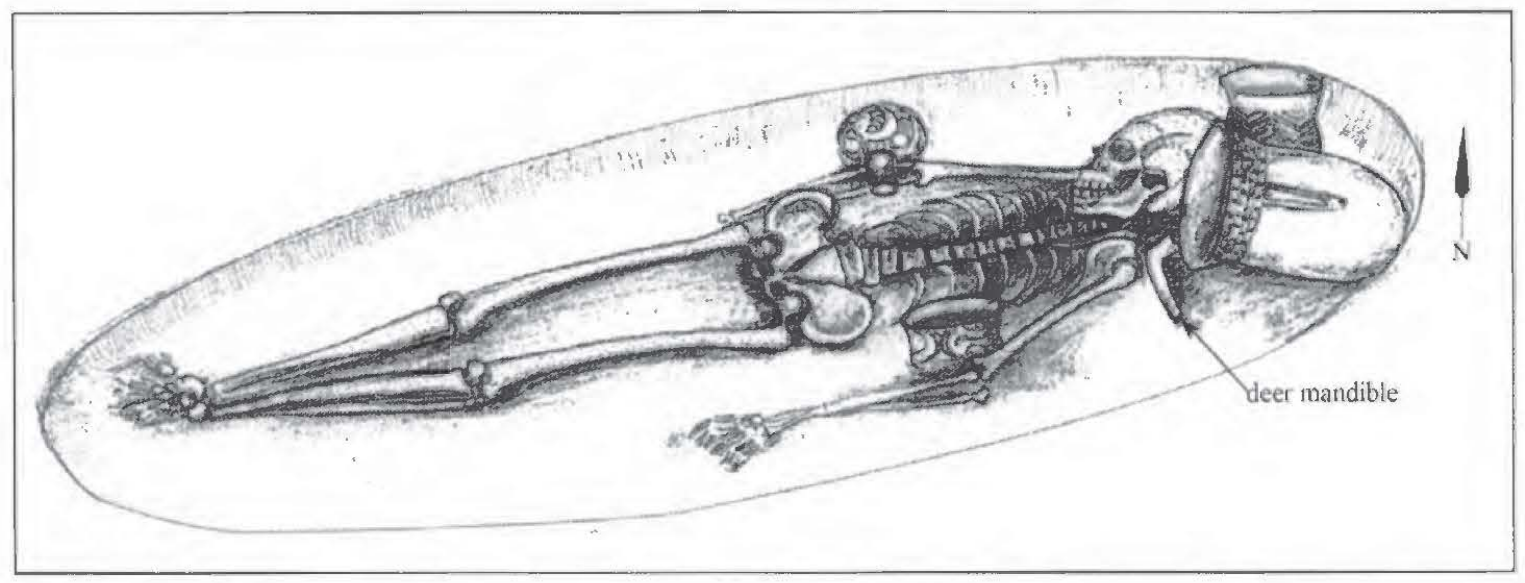

Figure 6. Plan map of Burial No. 6.

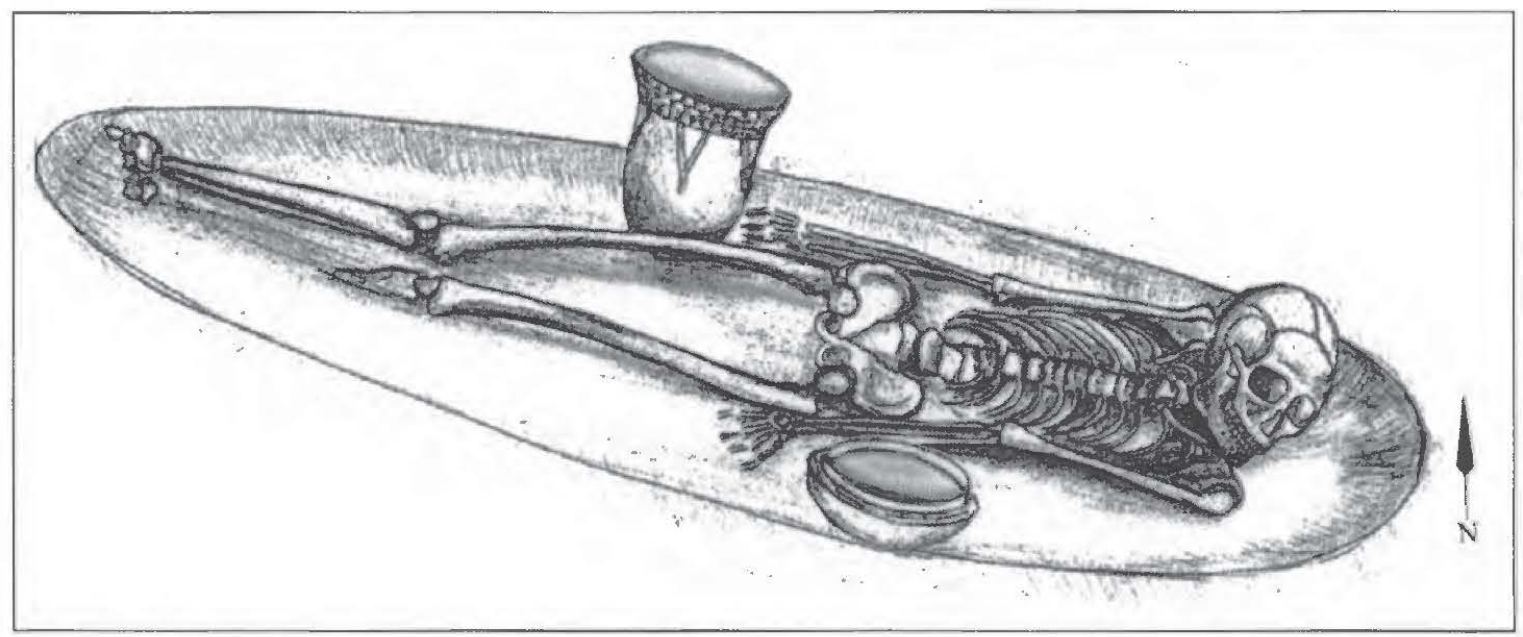

Figure 7. Plan map of Burial No. 7.

Burial No. 8 excavated by Buddy Calvin Jones at the Sam Kaufman site was that of a child or adolescent. The burial pit was $4 \mathrm{ft}$. in length and $2 \mathrm{ft}$. wide (Figure 8), and had a depth of $2 \mathrm{ft}$. bs. Notes included with the burial plan map indicate that Burial No. 8 was dug by the Caddo in a $1.3 \mathrm{ft}$. thick midden deposit, perhaps near a house location in the village, extending $0.7 \mathrm{ft}$. into a dark red and compact clay B-horizon.

The child or adolescent was accompanied at death with seven ceramic vessels. Six of them were placed along the right side of the body, from the head to its right leg. These include, from top to bottom, an Emory Punctated-Incised jar, two Hudson Engraved bottles, a second Emory Punctated-Incised jar, an Avery Engraved deep bowl, and a third Emory Punctated-Incised jar. One small Avery Engraved bowl was set on its waist. 


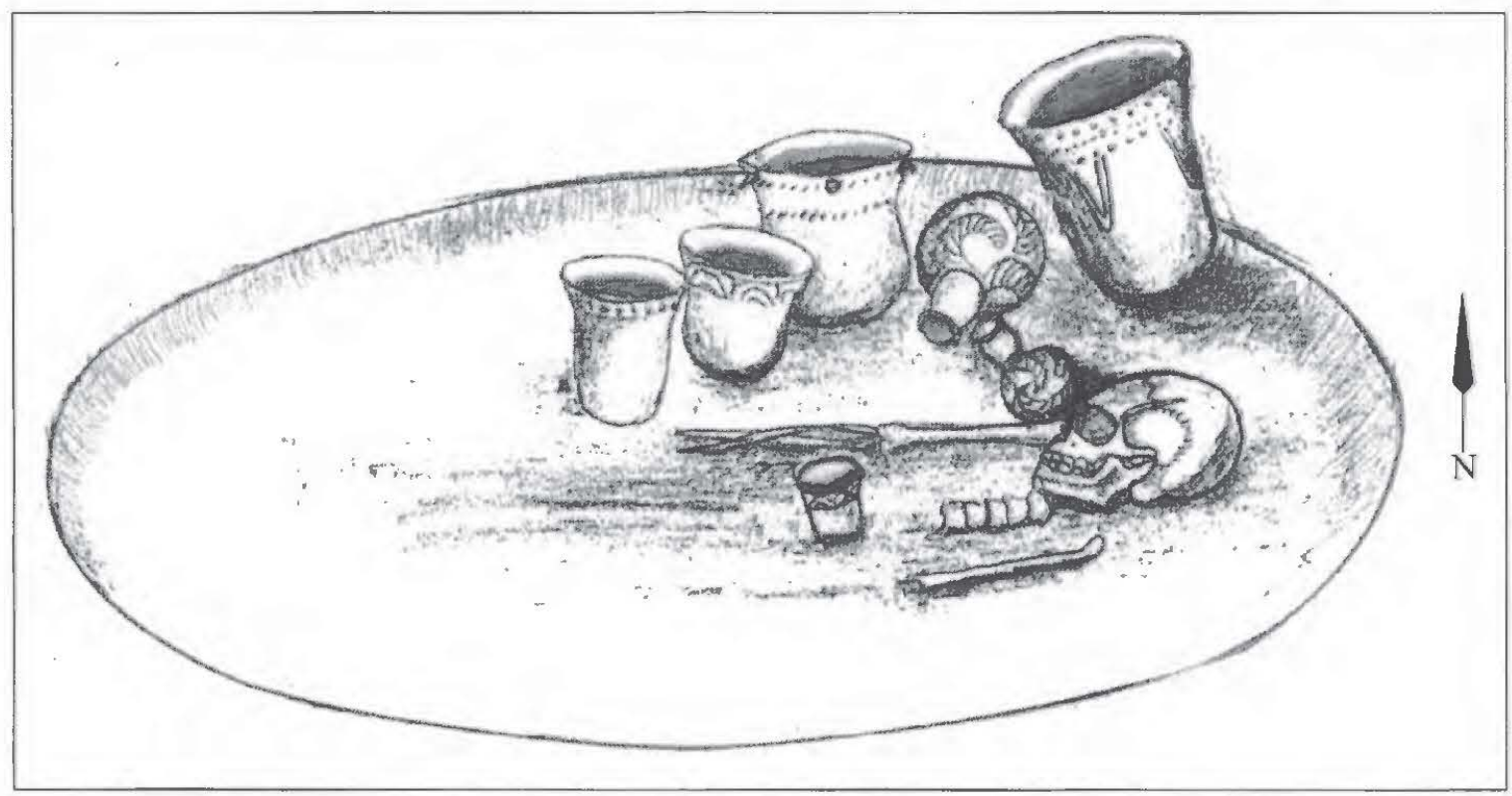

Figure 8. Plan map of Burial No. 8.

\section{VESSEL DESCRIPTIONS}

In the GCHM are 22 vessels or vessel sections from the Sam Kaufman site (41RR16). Only a few of the vessels can be definitively identified at the present time with specific burials excavated by Jones, unfortunately. Each vessel or vessel section is described individually, following the burial vessel protocol that we adopted some years ago (Perttula et al. 1998; Perttula 2005) when we began actively documenting Caddo vessels from sites in East Texas and southwest Arkansas. In addition to several shell-tempered plain vessels $(n=3)$, and unidentified incised $(n=1)$ and appliqued $(n=1)$ vessels, other shell-tempered vessels and vessel sections we have documented from the cemetery excavated by Jones in 1961-1962 include Avery Engraved $(n=1)$, Emory Punctated-Incised ( $n=2)$, Hudson Engraved ( $n=5)$, Keno Trailed ( $n=1)$, McKinney Plain $(n=1)$, Nash Neck Banded $(n=5)$, Simms Engraved $(n=1)$, There is also a grog-tempered Maxey Noded Redware bottle.

\section{SITE NAME OR SITE NUMBER: Sam Kaufman, Burial No. 2}

VESSEL NO.: 2003.08.1237

NON-PLASTICS AND PASTE: shell

VESSEL FORM: Bottle with a wide-mouth

RIM AND LIP FORM: N/A

CORE COLOR: A (fired and cooled in an oxidizing environment)

INTERIOR SURFACE COLOR: red

EXTERIOR SURFACE COLOR: red

WALL THICKNESS (RIM, BODY, AND BASE IN MM): body, $7.6 \mathrm{~mm}$ 
INTERIOR SURFACE TREATMENT: none

EXTERIOR SURFACE TREATMENT: none

HEIGHT (IN CM): N/A

ORIFICE DIAMETER (IN CM): 8.2

DIAMETER AT BOTTOM OF RIM OR NECK (IN CM): 8.2

BASE DIAMETER (IN CM): N/A

ESTIMATED VOLUME (IN LITERS): N/A

DECORATION (INCLUDING MOTIF AND ELEMENTS WHEN APPARENT): Plain

PIGMENT USE AND LOCATION ON VESSEL: none

TYPE [IF KNOWN]: Unidentified plain ware. Associated with Individual No. 2 (see Figure 3).

\section{SITE NAME OR SITE NUMBER: Sam Kaufman, Burial No. 2}

VESSEL NO.: 2003.08.1238

NON-PLASTICS AND PASTE: shell

VESSEL FORM: Bowl with a very short rim

RIM AND LIP FORM: direct rim and a rounded, exterior folded lip

CORE COLOR: B (fired and cooled in a reducing environment)

INTERIOR SURFACE COLOR: very lark grayish-brown

FXTERIOR SURFACE COLOR: very dark grayish-brown; fire clouding on the body

WALL THICKNESS (RIM, BODY, AND BASE IN MM): rim, $2.8 \mathrm{~mm}$; body, $5.8 \mathrm{~mm}$; base, $7.0 \mathrm{~mm}$

INTERIOR SURFACE TREATMENT: smoothed

EXTERIOR SURFACE TREATMENT: smoothed

HEIGHT (IN CM): 6.0

ORIFICE DIAMETER (IN CM): 10.0

DIAMETER AT BOTTOM OF RIM OR NECK (IN CM): 5.9

BASE DIAMETER (IN CM): 4.5

ESTIMATED VOLUME (IN LITERS): 0.24

DECORATION (INCLUDING MOTIF AND ELEMENTS WHEN APPARENT): Plain (Figure 9)

PIGMENT USE AND LOCATION ON VESSEL: none

IYYPE [IF KNOWN]: Unidentified plain ware 


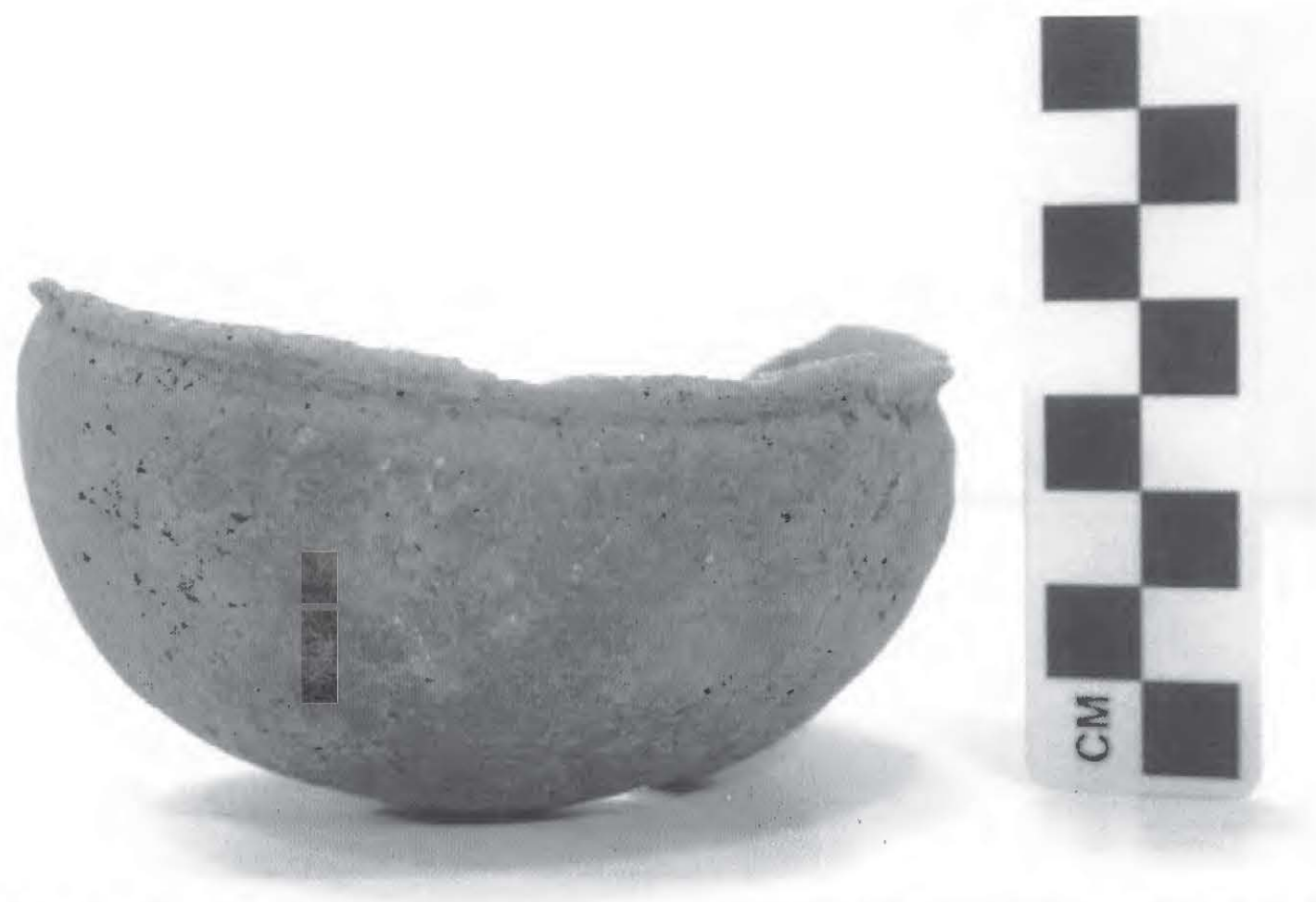

Figure 9. Plain shell-tempered bowl, Burial 2 at the Sam Kaufman site. This vessel is associated with Burial individual No. 1 (see Figure 3).

SITE NAME OR SITE NUMBER: Sam Kaufman, Burial No. 3

VESSEL NO.: 2003.08.1117

NON-PLASTICS AND PASTE: shell

VESSEL FORM: Jar with short neck (Figure 10)

RIM AND LIP FORM: everted rim and a rounded, exterior folded lip

CORE COLOR: B (fired and cooled in a reducing environment)

INTERIOR SURFACE COLOR: very dark grayish-brown

EXTERIOR SURFACE COLOR: very dark grayish-brown; fire clouding on the body and base

WALL THICKNESS (RIM, BODY, AND BASE IN MM): rim, $5.2 \mathrm{~mm}$

INTERIOR SURFACE TREATMENT: smoothed

EXTERIOR SURFACE TREATMENT: burnished

HEIGHT (IN CM): 12.0

ORIFICE DIAMETER (IN CM): 13.5

DIAMETER AT BOTTOM OF RIM OR NECK (IN CM): 10.9

BASE DIAMETER (IN CM): 8.8 


\section{ESTIMATED VOLUME (IN LITERS): 0.97}

DECORATION (INCLUDING MOTIF AND ELEMENTS WHEN APPARENT): The vessel rim is plain, except for three sets of small appliqué nodes; it is also lip notched. The vessel body has three repeating sets of narrow curvilinear zones filled with cross-hatched engraved lines (Figure 10). These zones form scrolls that end in hooked arms as well as large cross-hatched elements, and there are upper and lower engraved triangles on either side of the large cross-hatched scrolls. There are also single curvilinear and ticked engraved lines that hook around two of the narrow cross-hatched zones.

PIGMENT USE AND LOCATION ON VESSEL: none

TYPE [IF KNOWN]: Hudson Engraved

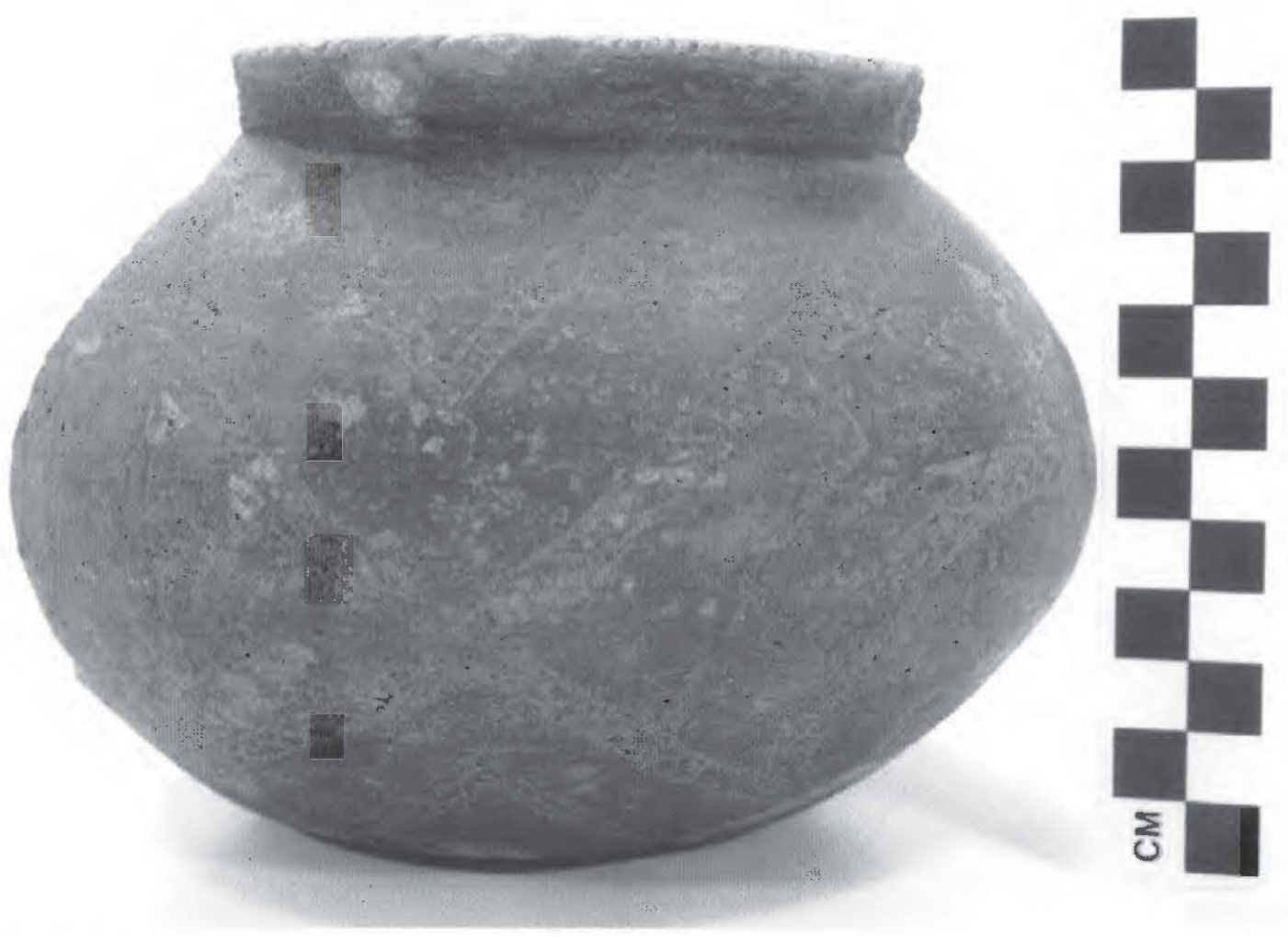

Figure 10. Hudson Engraved jar, Burial No. 3 at the Sam Kaufman Site.

SITE NAME OR SITE NUMBER: Sam Kaufman, Burial No. 5

VESSEL NO.: 2003.08.1125

NON-PLASTICS AND PASTE: shell

VESSEL FORM: Bottle 
10 Journal of Northeast Texas Archaeology 36 (20/2)

RIM AND LIP FORM: N/A

CORE COLOR: $\mathrm{F}$ (fired in a reducing environment and cooled in the open air)

INTERIOR SURFACE COLOR: dark yellowish-brown

EXTERIOR SURFACE COLOR: dark yellowish-brown

WALL THICKNESS (RIM, BODY, AND BASE IN MM): body, $4.1 \mathrm{~mm}$

INTERIOR SURFACE TREATMENT: none

EXTERIOR SURFACE TREATMENT: smoothed

HEIGHT (IN CM): N/A

ORIFICE DIAMETER (IN CM): N/A

DIAMETER AT BOTTOM OF RIM OR NECK (IN CM): N/A; maximum body diameter is $12.0 \mathrm{~cm}$

BASE DIAMETER (IN CM): 7.0

ESTIMATED VOLUME (IN LITERS): N/A

DECORATION (INCLUDING MOTIF AND ELEMENTS WHEN APPARENT): Plain

PIGMENT USE AND LOCATION ON VESSEL: none

TYPE [IF KNOWN]: Inidentified plain warc

\section{SITE NAME OR SITE NUMBER: Sam Kaufman, Burial No. 7}

VESSEL NO.: 2003.08.977-a

NON-PLASTICS AND PASTE: shell

VESSEL FORM: Jar

RIM AND LIP FORM: everted rim and rounded lip

CORE COLOOR: $\mathrm{B}$ (fired and cooled in a reducing environment)

INTERIOR SURFACE COLOR: dark gray

EXTERIOR SURFACE COLOR: dark gray

WALL THICKNESS (RIM, BODY, AND BASE IN MM): rim, $4.1 \mathrm{~mm}$

INTERIOR SURFACE TREATMENT: smoothed

EXTERIOR SURFACE TREATMENT: none

HEIGHT (IN CM): N/A

ORIFICE DIAMETER (IN CM): 20.0

DIAMETER AT BOTTOM OF RIM OR NECK (IN CM): N/A 
BASE DIAMETER (IN CM): N/A

ESTIMATED VOLUME (IN LITERS): N/A

DECORATION (INCLUDING MOTIF AND ELEMENTS WHEN APPARENT): There are three rows of neck banding on the vessel rim, along with appliqued nodes (probably four) above the neck banding and below the vessel lip.

PIGMENT USE AND LOCATION ON VESSEL: none

TYPE [IF KNOWN]: Nash Neck Banded

SITE NAME OR SITE NUMBER: Sam Kaufman, Burial No. 7

VESSEL NO.: 2003.08.977-b

NON-PLASTICS AND PASTE: shell

VESSEL FORM: Bottle

RIM AND LIP FORM: N/A

CORE COLOR: $\mathrm{B}$ (fired and cooled in a reducing environment)

INTERIOR SURFACE COLOR: dark gray

EXTERIOR SURFACE COLOR: dark gray

WALL THICKNESS (RIM, BODY, AND BASE IN MM): body, $6.3 \mathrm{~mm}$

INTERIOR SURFACE TREATMENT: none

EXTERIOR SURFACE TREATMENT: none

HEIGHT (IN CM): N/A

ORIFICE DIAMETER (IN CM): N/A

DIAMETER AT BOTTOM OF RIM OR NECK (IN CM): N/A

BASE DIAMETER (IN CM): N/A

ESTIMATED VOLUME (IN LITERS): N/A

DECORATION (INCLUDING MOTIF AND ELEMENTS WHEN APPARENT): The vessel has narrow engraved scroll zones filled with hatched lines.

PIGMENT USE AND LOCATION ON VESSEL: none

TYPE [IF KNOWN]: Hudson Engraved

\section{SITE NAME OR SITE NUMBER: Sam Kaufman, Burial No. 7}

VESSEL NO.: 2003.08.977c

NON-PLASTICS AND PASTE: shell 
VESSEL FORM: Shouldered bowl

RIM AND LIP FORM: inverted rim and a rounded lip

C.ORE COLOR: B (fired and cooled in a reducing environment)

INTERIOR SURFACE COLOR: black

EXTERIOR SURFACE COLOR: black

WALL THICKNESS (RIM, BODY, AND BASE IN MM): rim, 4.8 mm

INTERIOR SURFACE TREATMENT: bumished

EXTERIOR SURFACE TREATMENT: burnished

HEIGHT (IN CM): N/A

ORIFICE DIAMETER (IN CM): 15.0

DIAMETER AT BOTTOM OF RIM OR NECK (IN CM): N/A

BASE DIAMETER (IN CM): N/A

ESTIMATED VOLUME (IN LITERS): N/A

DECORATION (INCLUDING MOTIF AND ELEMENTS WHEN APPARENT): The rim of the vessel is plain, except for a notched lip. The vessel body has a single horizontal engraved line with tick marks on it.

PIGMENT USE AND LOCATION ON VESSEL: none

TYPE [IF KNOWN]: Simms Engraved

SITE NAME OR SITE NUMBER: Sam Kaufman

VESSEL NO.: 2003.08.1118

NON-PLASTICS AND PASTE: shell

VESSEL FORM: Jar

RIM AND LIP FORM: everted rim and a rounded lip

CORE COLOR: B (fired and cooled in a reducing environment)

INTERIOR SURFACE COLOR: very dark grayish-brown

EXTERIOR SURFACE COLOR: dark grayish-brown

WALL THICKNESS (RIM, BODY, AND BASE IN MM): rim, 6.2 mm; body, 5.1 mm

INTERIOR SURFACE TREATMENT: none

EXTERIOR SURFACE TREATMENT: none

HEIGHT (IN CM): 15.6

ORIFICE DIAMETER (IN CM): 18.0 
DIAMETER AT BOTTOM OF RIM OR NECK (IN CM): 18.3

BASE DIAMETER (IN CM): 6.5; dimpled base

ESTIMATED VOLUME (IN LITERS): 1.68

DECORATION (INCLUDING MOTIF AND ELEMENTS WHEN APPARENT): There are six rows of horizontal neck bands on the rim, as well as four appliqued nodes near the lip. The upper vessel body has four appliqued chevrons, centered under the appliqued nodes (Figure 11).

PIGMENT USE AND LOCATION ON VESSEL: none

TYPE [IF KNOWN]: Nash Neck Banded

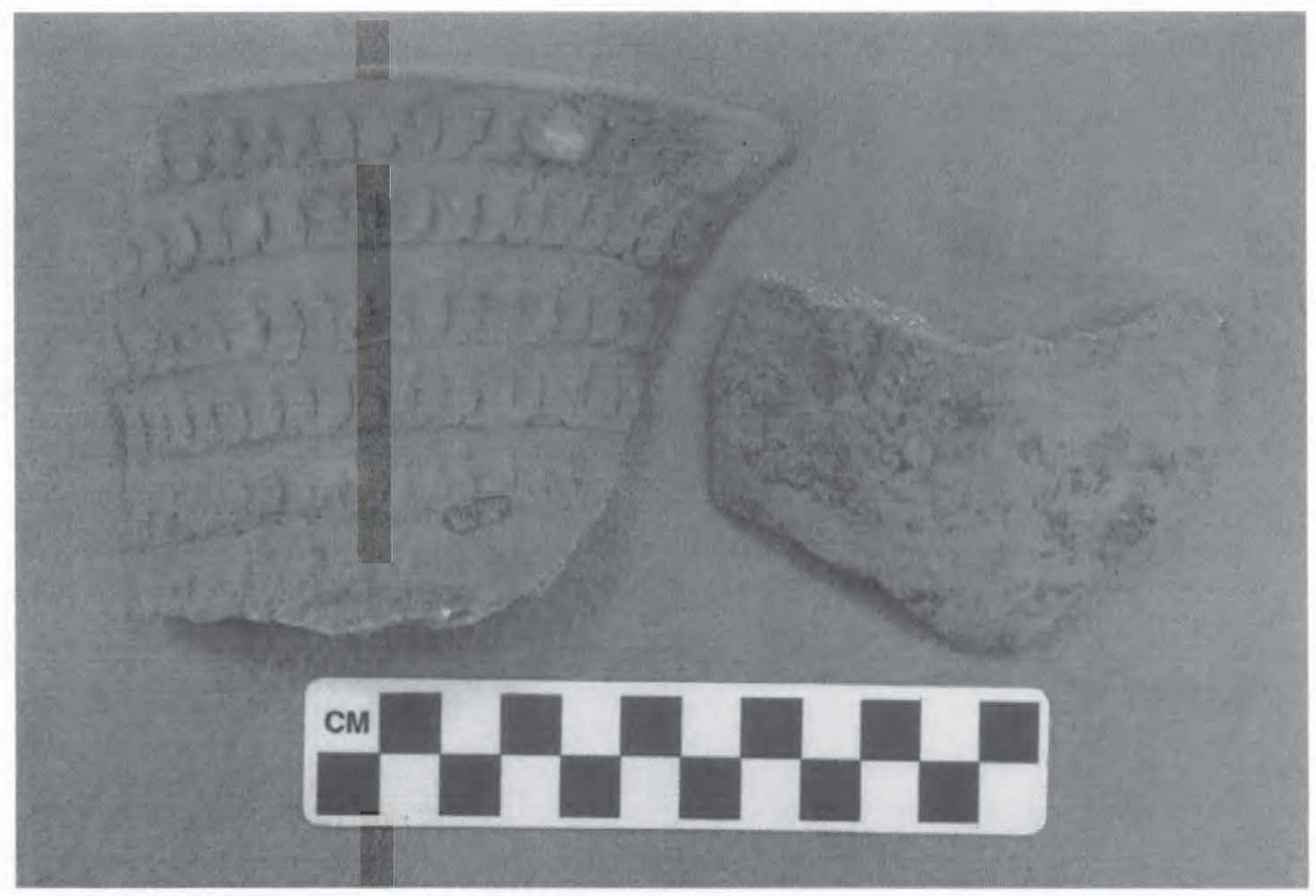

Figure 11, Nash Neck Banded jar from the Sam Kaufman site.

\section{SITE NAME OR SITE NUMBER: Sam Kaufman}

VESSEL NO.: 2003.08.1119

NON-PLASTICS AND PASTE: shell

VESSEL FORM: Jar

RIM AND LIP FORM: everted rim and a rounded lip

CORE COLOR: $F$ (fired in a reducing environment and cooled in the open air)

INTERIOR SURFACE COLOR: dark yellowish-brown 
EXTERIOR SURFACE COLOR: dark yellowish-brown

WALL THICKNESS (RIM, BODY, AND BASE IN MM): rim, $5.2 \mathrm{~mm}$; body, $5.1 \mathrm{~mm}$; base, $7.9 \mathrm{~mm}$

INTERIOR SURFACE TREATMENT: smoothed

EXTERIOR SURFACE TREATMENT: none

HEIGHT (IN CM): 13.5

ORIFICE DIAMETER (IN CM): 14.5

DIAMETER AT BOTTOM OF RIM OR NECK (IN CM): 12.0

BASE DIAMETER (IN CM): 6.6

ESTIMATED VOLUME (IN

LITERS): 1.2

DECORATION (INCLUDING MOTIF AND ELEMENTS WHEN APPARENT): The rim has three equally-spaced horizontal rows of tool punctations, as well as four appliqued nodes set above the punctations (Figure 12). The upper vessel body has four sets of curvilinear appliqued fillets, centered on the body between each of the appliqued nodes on the rim. This vessel closely matches the drawing of one of the vessels in Burial No. 8 (see Figure 8).

PIGMENT USE AND LOCATION

ON VESSEL: none

TYPE [IF KNOWN]: Emory

Punctated-Incised

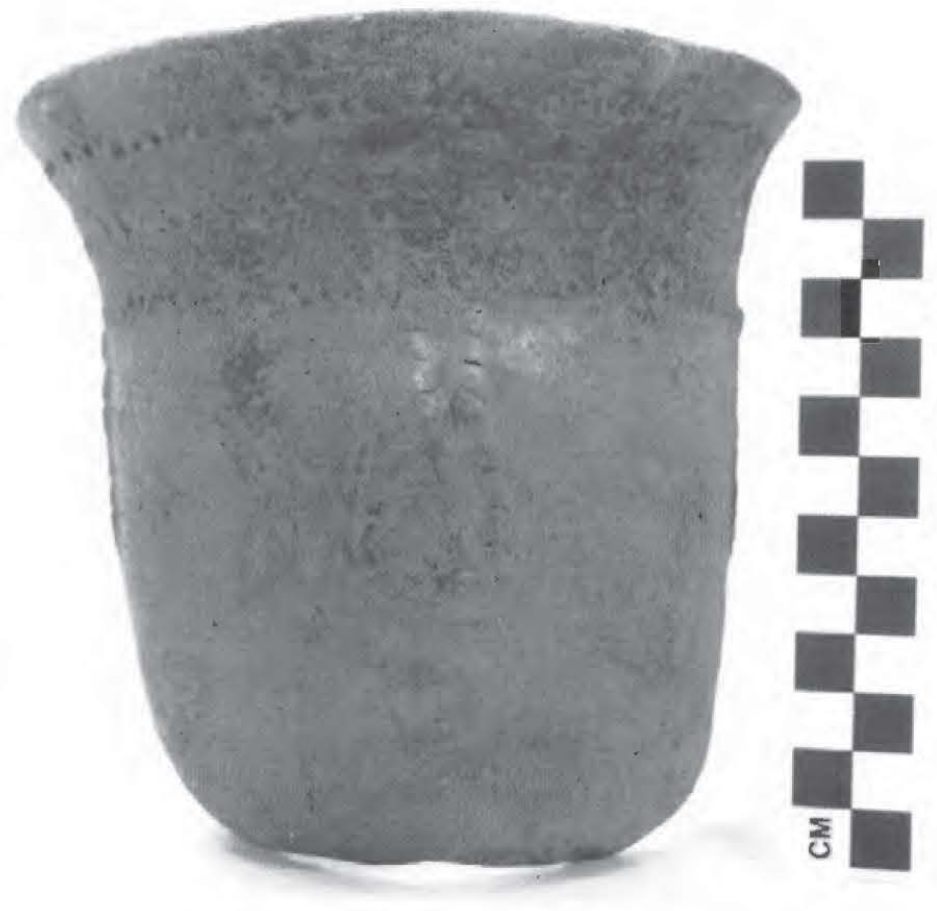

Figure 12. Emory Punctated-Incised jar from the Sam Kaufman site.

SITE NAME OR SITE NUMBER: Sam Kaufman

VESSEL NO.: 2003.08.1120a

NON-PLASTICS AND PASTE: shell

VESSEL FORM: Jar

RIM AND LIP FORM: everted rim and a rounded, exterior folded lip

CORE COLOR: B (fired and cooled in a reducing environment)

INTERIOR SURFACE COLOR: dark grayish-brown

EXTERIOR SURFACE COLOR: dark grayish-brown

WALL THICKNESS (RIM, BODY, AND BASE IN MM): rim, $4.9 \mathrm{~mm}$ 
INTERIOR SURFACE TREATMENT: smoothed

EXTERIOR SURFACE TREATMENT: none

HEIGHT (IN CM): N/A

ORIFICE DIAMETER (IN CM): N/A

DIAMETER AT BOTTOM OF RIM OR NECK (IN CM): N/A

BASE DIAMETER (IN CM): N/A

ESTIMATED VOLUME (IN LITERS): N/A

DECORATION (INCLUDING MOTIF AND ELEMENTS WHEN APPARENT): The jar has at least one row of neck banding. and there are appliqued nodes (probably four) under the vessel lip.

PIGMENT USE AND LOCATION ON VESSEL: none

TYPE [IF KNOWN]: Nash Neck Banded

\section{SITE NAME OR SITE NUMBER: Sam Kaufman}

VESSEL NO:: 2003.08.1120b

NON-PLASTICS AND PASTE: shell

VESSEL FORM: Jar

RIM AND LIP FORM: N/A

CORE COLOR: $\mathrm{F}$ (fired in a reducing environment and cooled in the open air)

INTERIOR SURFACE COLOR: dark yellowish-brown

EXTERIOR SURFACE COLOR: dark yellowish-brown

WALL THICKNESS (RIM, BODY, AND BASE IN MM): body, $5.7 \mathrm{~mm}$

INTERIOR SURFACE TREATMENT: smouthed

EXTERIOR SURFACE TREATMENT: none

HEIGHT (IN CM): N/A

ORIFICE DIAMETER (IN CM): N/A

DIAMETER AT BOTTOM OF RIM OR NECK (IN CM): N/A

BASE DIAMETER (IN CM): N/A

ESTIMATED VOLUME (IN LITERS): N/A

DECORATION (INCLUDING MOTIF AND ELEMENTS WHEN APPARENT): The vessel body has incised triangles (probably pendant from the rim-body juncture) filled with diagonal incised lines.

PIGMENT USE AND LOCATION ON VESSEL: none

TYPE [IF KNOWN]: Emory Punctated-Incised 
16 Journal of Northeast Texas Archaeology 36 (2012)

\section{SITE NAME OR SITE NUMBER: Sam Kaufman}

VESSEL NO:: 2003.08.1120c

NON-PLASTICS AND PASTE: shell

VESSEL FORM: Jar with four appliqued lugs on the rim

RIM AND LIP FORM: everted rim and a rounded lip

CORF, COLOR: $\mathrm{F}$ (fired in a reducing environment and cooled in the open air)

INTERIOR SURFACE COLOR: dark yellowish-brown

EXTERIOR SURFACE COIOR: dark ycllowish-brown

WALL THICKNESS (RIM, BODY, AND BASE IN MM): rim, $5.4 \mathrm{~mm}$; body, $4.6 \mathrm{~mm}$; base, $5.9 \mathrm{~mm}$

INTERIOR SURFACE TREATMENT: smoothed

EXTERIOR SURFACE TREATMENT: smoothed

HEIGHT (IN CM): 21.5

ORIFICE DIAMETER (IN CM): 17.0

DIAMETER AT BOTTOM OF RIM OR NECK (IN CM): 12.4

BASE DIAMETER (IN CM): 7.8

ESTIMATED VOLUME (IN LITERS): 3.2

DECORATION (INCLUDING MOTIF AND ELEMENTS WHEN APPARENT): The rim is decorated with three rows of horizontal neck bands sandwiched between four appliqued lugs. The vesscl body has four sets of narrow triangular-shaped appliqued fillet elements that are pendant from the rim-body juncture (Figure 13).

PIGMENT USE AND LOCATION ON VESSEL: none

TYPE [IF KNOWN]: Nash Neck Banded

\section{SITE NAME OR SITE NUMBER: Sam Kaufman}

VESSEL NO.: 2003.08.1121

NON-PLASTICS AND PASTE: shell

VESSEL FORM: Jar

RIM AND LIP FORM: everted rim and rounded lip

CORE COLOR: $\mathrm{B}$ (fired and cooled in a reducing environment)

INTERIOR SURFACE COLOR: black; organic residue on the rim and body

EXTERIOR SURFACE COLOR: black; organic residue on the body 


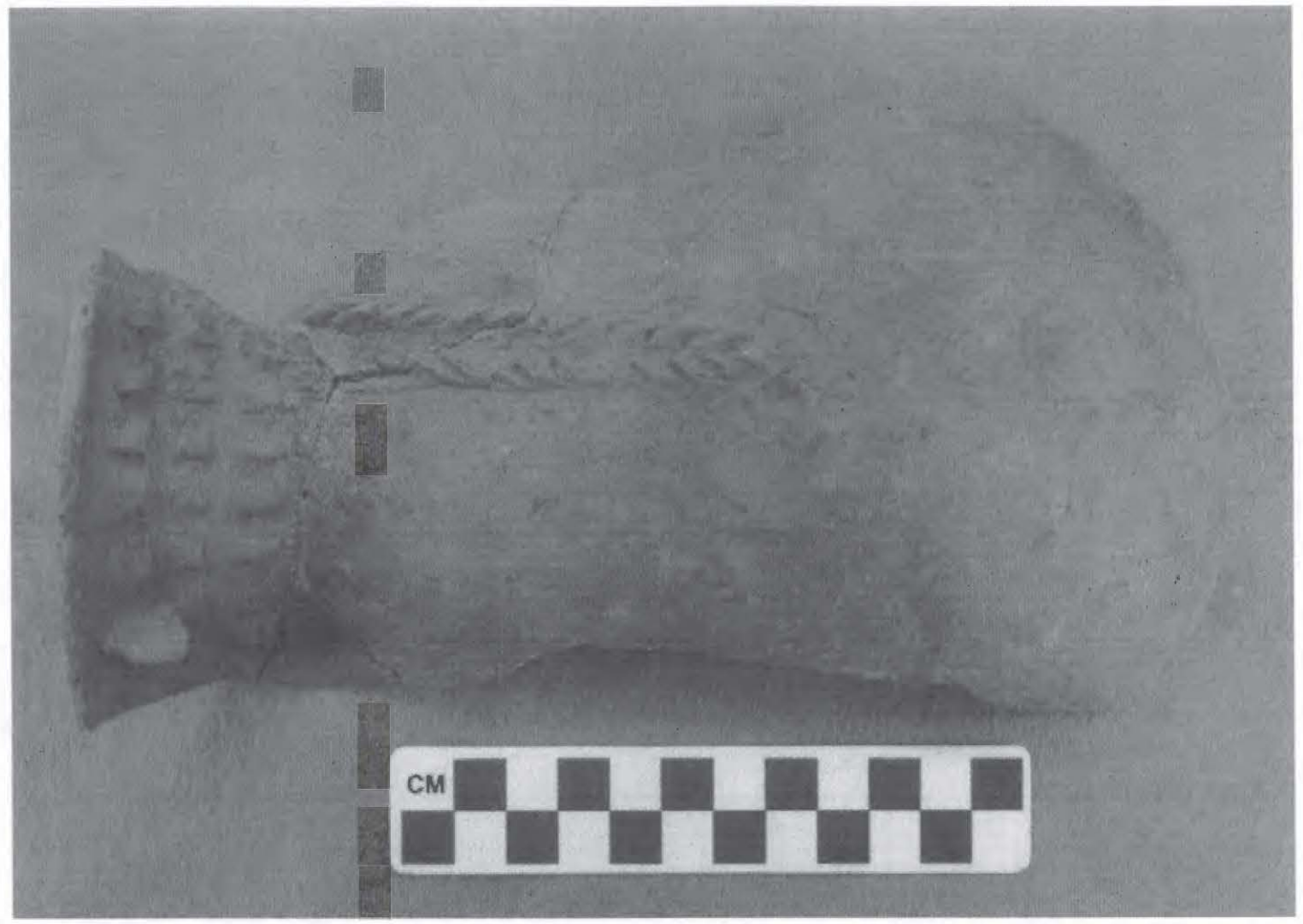

Figure 13. Nash Neck Banded jar from the Sam Kaufman site. This vessel closely matches a Nash Neck Banded jar depicted in the Burial No. 6 plan map (see Figure 6).

WALL THICKNESS (RIM, BODY, AND BASE IN MM): rim, $4.3 \mathrm{~mm}$; body, $5.3 \mathrm{~mm}$

INTERIOR SURFACE TREATMENT: smoothed

EXTERIOR SURFACE TREATMENT: smoothed

HEIGHT (IN CM): N/A; rim height is $1.8 \mathrm{~cm}$

ORIFICE DIAMETER (IN CM): 11.0

DIAMETER AT BOTTOM OF RIM OR NECK (IN CM): 10.6

BASE DIAMETER (IN CM): N/A

ESTIMATED VOLUME (IN LITERS): N/A

DECORATION (INCLUDING MOTIF AND ELEMENTS WHEN APPARENT): The vessel rim is plain, while the vessel body has four sets of appliqued ridge chevron elements that are pendant from the rimbody juncture (Figure 14).

PIGMENT USE AND LOCATION ON VESSEL: none

TYPE [IF KNOWN]: possible McKinney Plain 


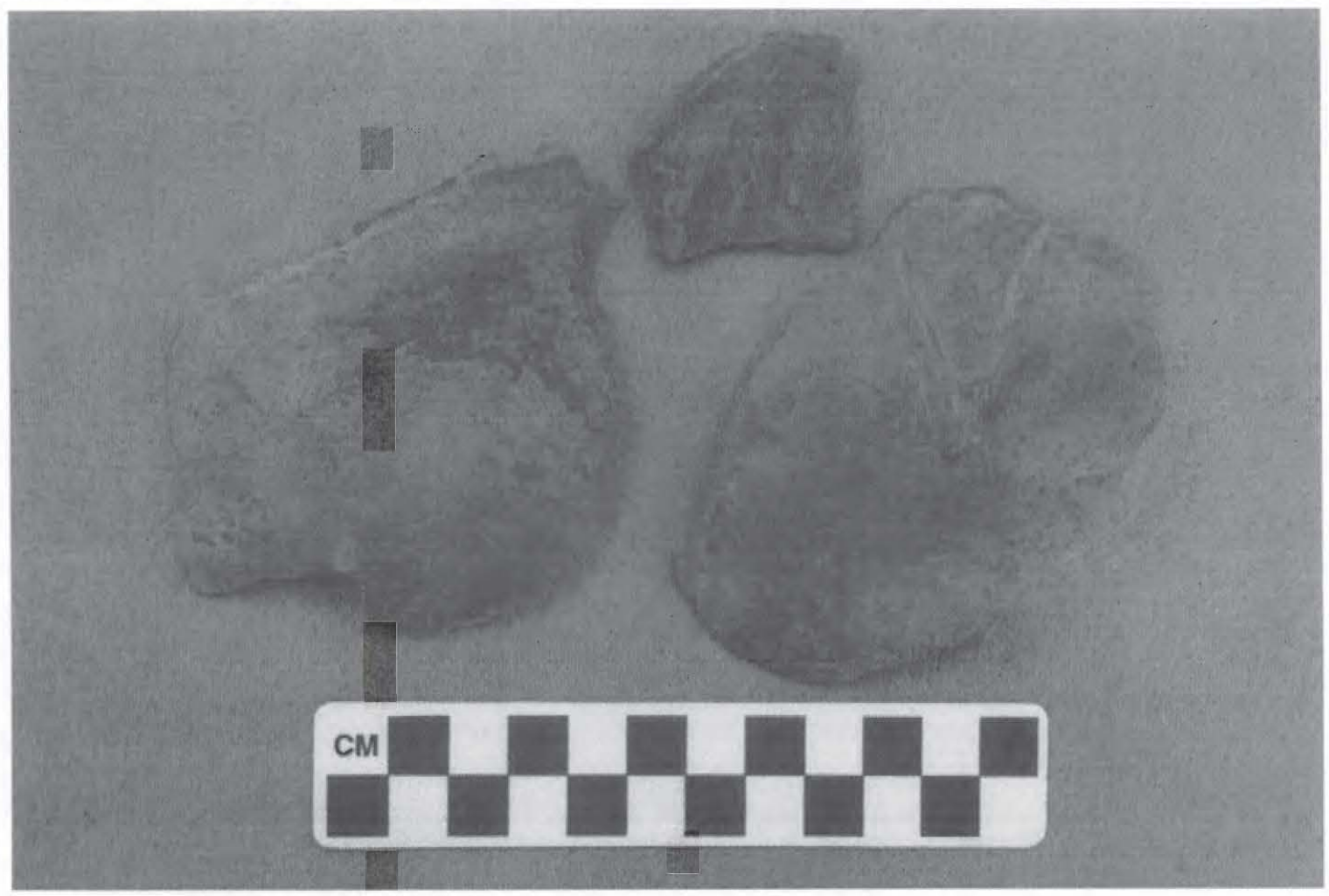

Figure 14. Possible McKinney Plain jar.

SITE NAME OR SITE NUMBER: Sam Kaufman

VESSEL NO.: 2003.08.1122

NON-PLASTICS AND PASTE: shell

VESSEL FORM: Bowl

RIM AND LIP FORM: everted-rounded

CORE COLOR: F (fired in a reducing environment and cooled in the open air)

INTERIOR SURFACE COLOR: red

EXTERIOR SURFACE COLOR: red

WALL THICKNESS (RIM, BODY, AND BASE IN MM): body, $5.5 \mathrm{~mm}$; base, $5.7 \mathrm{~mm}$

INTERIOR SURFACE TREATMENT: smoothed

EXTERIOR SURFACE TREATMENT: burnished

HEIGHT (IN CM): N/A

ORIFICE DIAMETER (IN CM): N/A

DIAMETER AT BOTTOM OF RIM OR NECK (IN CM): N/A 


\section{BASE DIAMETER (IN CM): 5.1}

\section{ESTIMATED VOLUME (IN LITERS): N/A}

DECORATION (INCLUDING MOTIF AND ELEMENTS WHEN APPARENT): The vessel has a red slip on both interior and exterior surfaces as well as curvilinear engraved and negative engraved elements, including ovals and excised zones (Figure 15).

\section{PIGMENT USE AND LOCATION ON VESSEL: none}

TYPE [IF KNOWN]: Avery Engraved

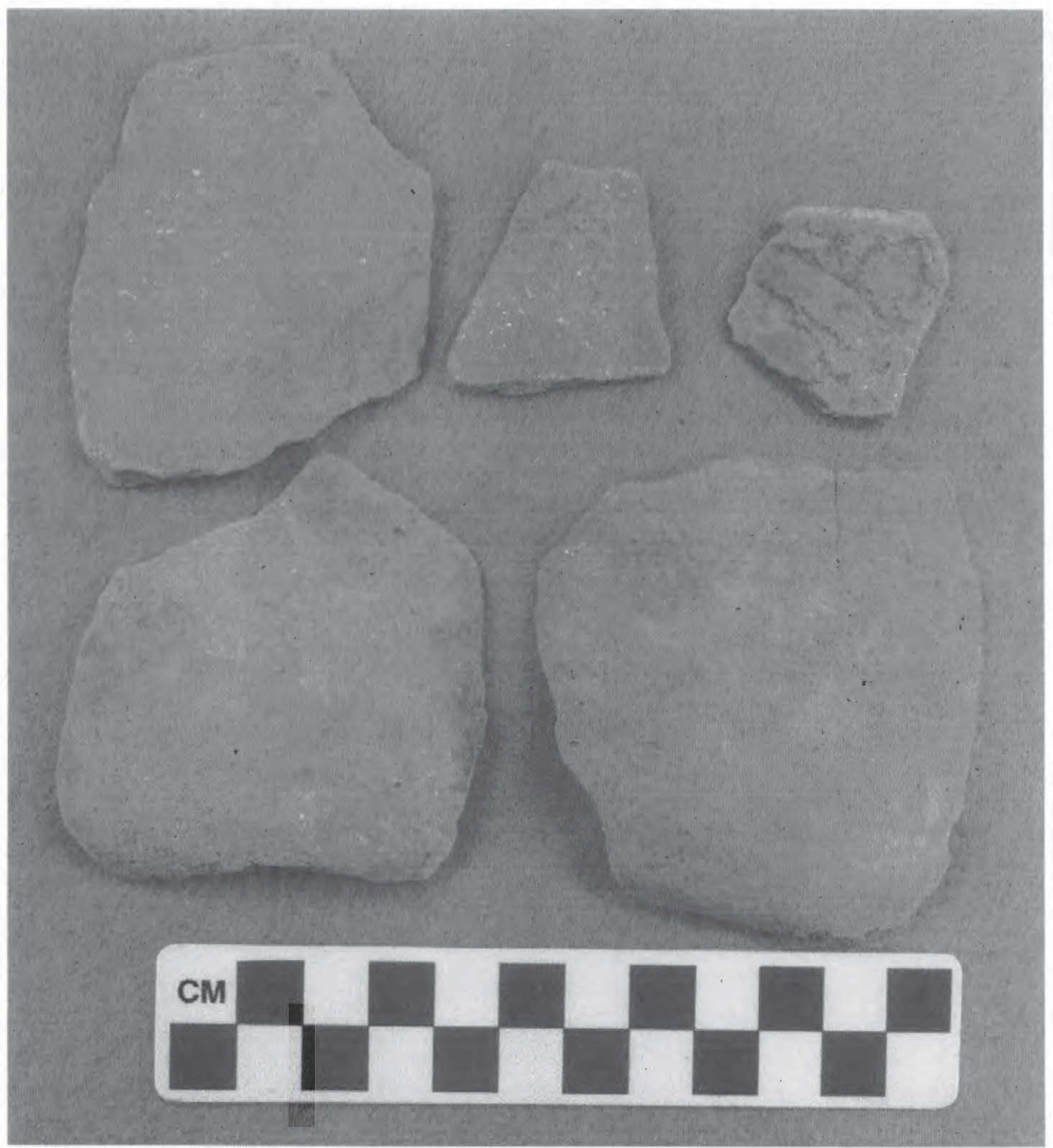

Figure 15. Avery Engraved bowl sherds from the Sam Kaufman site. 


\section{SITE NAME OR SITE NUMBER: Sam Kaufman}

VESSEL NO.: 2003.08.1123

NON-PLASTICS AND PASTE: shell

VESSEL FORM: Bottle

RIM AND LIP FORM: direct rim and a rounded, exterior folded lip

CORE COLOR: B (fired and cooled in a reducing environment)

INTERIOR SURFACE COLOR: dark grayish-brown

EXTERIOR SURFACE COLOR: very dark grayish-brown

WALLL THICKNESS (RIM, BODY, AND BASE IN MM): rim, $4.6 \mathrm{~mm}$; body, $4.6 \mathrm{~mm}$

INTERIOR SURFACE TREATMENT: none

EXTERIOR SURFACE TREATMENT: burnished

HEIGHT (IN CM): N/A

ORIFICE DIAMETER (IN CM): 2.2

DIAMETER AT BOTTOM OF RIM OR NECK (IN CM): N/A

BASE DIAMETER (IN CM): N/A

ESTIMATED VOLUME (IN LITERS): N/A

DECORATION (INCLUDING MOTIF AND ELEMENTS WHEN APPARENT): The vessel body has narrow engraved curvilinear $70 n e s$ and bracket-shaped elcments filled with hatched or opposed hatched engraved lines (Figure 16).

PIGMENT USE AND LOCATION ON VESSEL: none

TYPE [IF KNOWN]: Hudson Engraved

\section{SITE NAME OR SITE NUMBER: Sam Kaufman}

VESSEI, NO.: 2003.08.1124

NON-PLASTICS AND PASTE: shell

VESSEL FORM: Bottle

RIM AND LIP FORM: N/A

CORE COLOR: $\mathbf{B}$ (fired and cooled in a reducing environment)

INTERIOR SURFACE COLOR: dark grayish-brown

EXTERIOR SURFACE COLOR: dark grayish-brown

WALL THICKNESS (RIM, BODY, AND BASE IN MM): body, $8.1 \mathrm{~mm}$ 


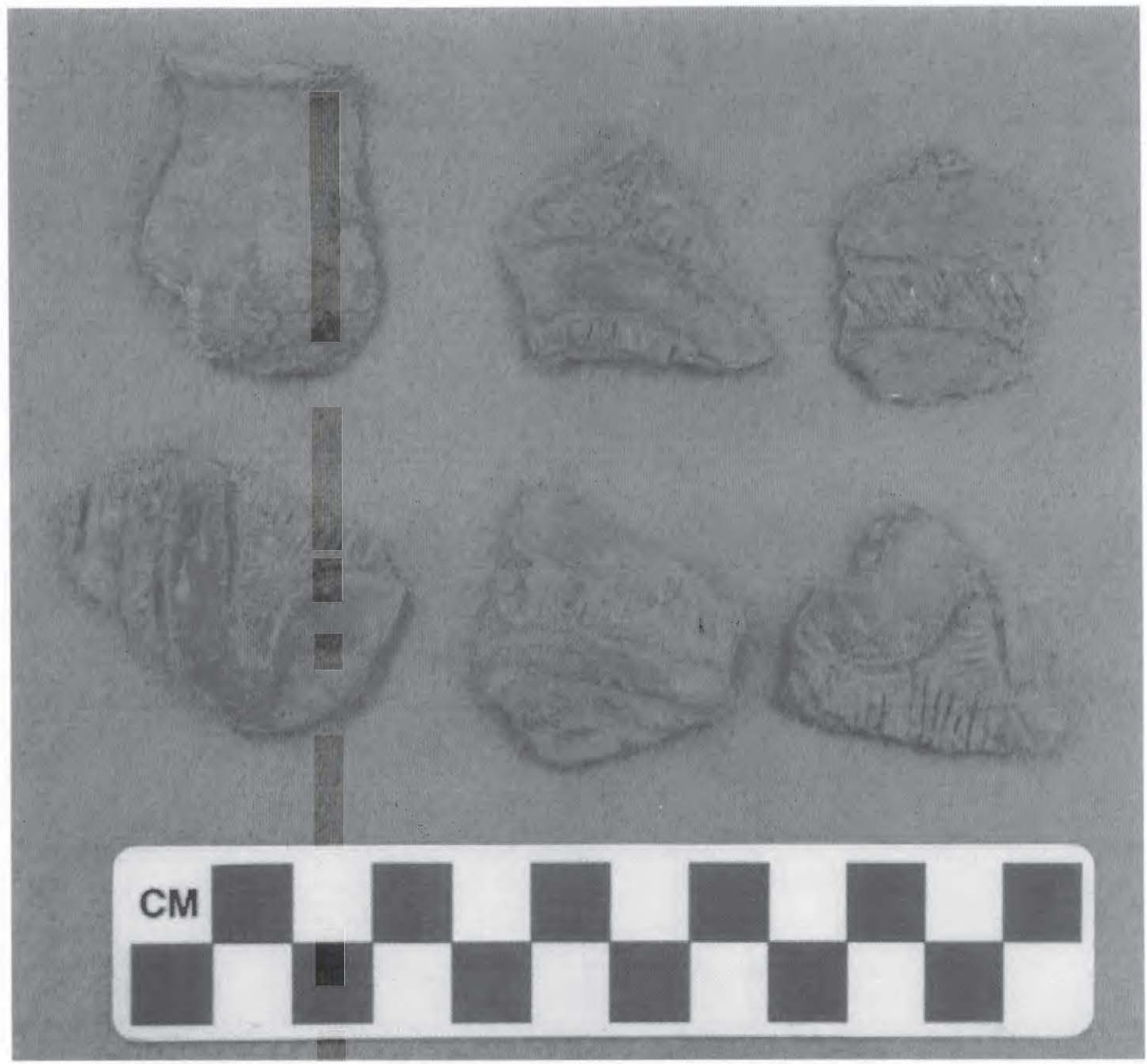

Figure 16. Hudson Engraved bottle sherds from the Sam Kaufman site.

INTERIOR SURFACE TREATMENT: none

EXTERIOR SURFACE TREATMENT: smoothed

HEIGHT (IN CM): N/A

ORIFICE DIAMETER (IN CM): N/A

DIAMETER AT BOTTOM OF RIM OR NECK (IN CM): N/A

BASE DIAMETER (IN CM): N/A

ESTIMATED VOLUME (IN LITERS): N/A

DECORATION (INCLUDING MOTIF AND ELEMENTS WHEN APPARENT): The vessel body and base has four sets of engraved meandering scrolls. The meandering scrolls are filled with hatched en- 
graved lines, as well as four sets of negative ovals, including at the central part of the first scroll (Figure 17).

\section{PIGMENT USE AND LOCATION ON VESSEL: none}

TYPE [IF KNOWN]: Hudson Engraved

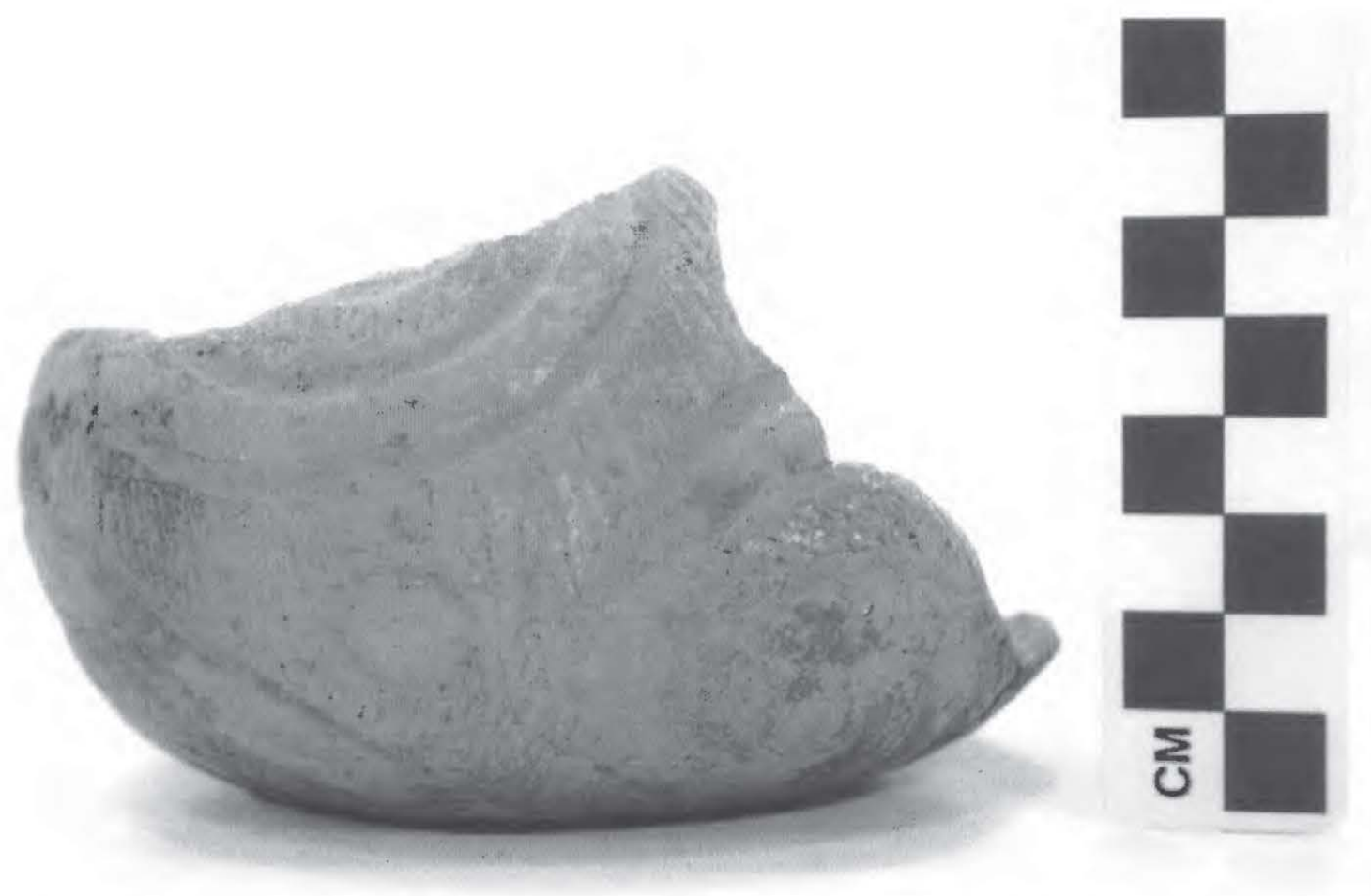

Figure 17. Partial Hudson Engraved bottle from the Sam Kaufman site. It closely matches a Hudson Engraved bottle in Burial No. 6 (see Figure 6).

\section{SITE NAME OR SITE NUMBER: Sam Kaufman}

VESSEL NO.: 2003.08.1228

NON-PLASTICS AND PASTE: shell

VESSEL FORM: Bottle

RIM AND LIP FORM: N/A

CORE COLOR: B (fired and cooled in a reducing environment)

INTERIOR SURFACE COLOR: dark grayish-brown

EXTERIOR SURFACE COLOR: dark grayish-brown

WALL THICKNESS (RIM, BODY, AND BASE IN MM): body, 4.I mm

INTERIOR SURFACE TREATMENT: none 
EXTERIOR SURFACE TREATMENT: none

HEIGHT (IN CM): N/A

ORIFICE DIAMETER (IN CM): N/A

DIAMETER AT BOTTOM OF RIM OR NECK (IN CM): N/A

BASE DIAMETER (IN CM): N/A

ESTIMATED VOLUME (IN LITERS): N/A

DECORATION (INCLUDING MOTIF AND ELEMENTS WHEN APPARENT): The vessel body is decorated with hatched engraved meandering scrolls.

PIGMENT USE AND LOCATION ON VESSEL: none

TYPE [IF KNOWN]: Hudson Engraved

\section{SITE NAME OR SITE NUMBER: Sam Kaufman}

VESSEL NO.: 2003.08.1240

NON-PLASTICS AND PASTE: grog

VESSEL FORM: Buttle

RIM AND LIP FORM: direct rim and a rounded lip

CORF COLOR: A (fired and cooled in an oxidizing environment)

INTERIOR SURFACE COLOR: light gray

EXTERIOR SURFACE COLOR: red

WALL THICKNESS (RIM, BODY, AND BASE IN MM): rim, $4.8 \mathrm{~mm}$; body, $5.3 \mathrm{~mm}$; base, $5.8 \mathrm{~mm}$

INTERIOR SURFACE TREATMENT: none

EXTERIOR SURFACE TREATMENT: burnished

HEIGHT (IN CM): N/A

ORIFICE DIAMETER (IN CM): 4.9

DIAMETER AT BOTTOM OF RIM OR NECK (IN CM): 5.6

BASE DIAMETER (IN CM): 7.3

ESTIMATED VOL.UME (IN LITERS): N/A

DECORATION (INCLUDING MOTIF AND ELEMENTS WHEN APPARENT): The vessel has a red slip on its exterior surface. The upper part of the vessel body has five sets of short appliqued ridges (Figure 18).

PIGMENT USE AND LOCATION ON VESSEL: none

TYPE [IF KNOWN]: Maxey Noded Redware 


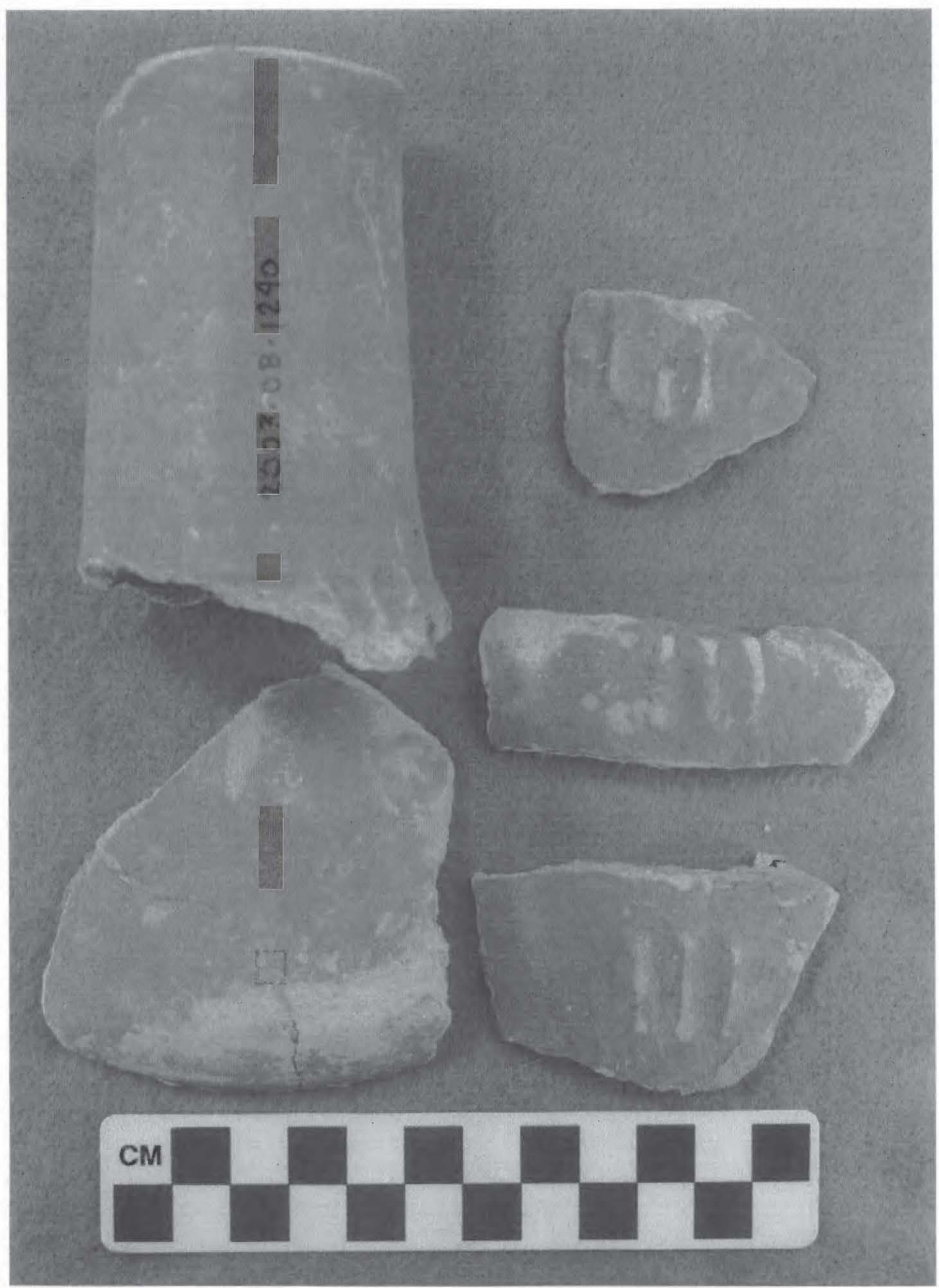

Figure 18. Maxey Noded Redware bottle from the Sam Kaufman site. 
SITE NAME OR SITE NUMBER: Sam Kaufman

VESSEL NO.: 2003.08.1513a

NON-PLASTICS AND PASTE: shell

VESSEL FORM: Jar

RIM AND LIP FORM: everted rim and rounded lip

CORE COLOR: B (fired and cooled in a reducing environment)

INTERIOR SURFACE COLOR: dark gray

EXTERIOR SURFACE COLOR: dark gray

WALL THICKNESS (RIM, BODY, AND BASE IN MM): rim, $5.9 \mathrm{~mm}$; bndy, $7.1 \mathrm{~mm}$

INTERIOR SURFACE TREATMENT: none

EXTERIOR SURFACE TREATMENT: none

HEIGHT (IN CM): N/A

ORIFICE DIAMETER (IN CM): 18.0

DIAMETER AT BOTTOM OF RIM OR NECK (IN CM): N/A

BASE DIAMETER (IN CM): N/A

ESTIMATED VOLUME (IN LITERS): N/A

DECORATION (INCLUDING MOTIF AND ELEMENTS WHEN APPARENT): The rim has two rows of tool punctations, and four appliqued nodes set amidst the uppermost tool punctated row. The vessel body has a triangular-shaped appliqued fillet clement repeated around the vessel, and centercd under the appliqued nodes.

PIGMENT USE AND LOCATION ON VESSEL: none

TYPE [IF KNOWN]: Emory Punctated-Incised

\section{SITE NAME OR SITE NUMBER: Sam Kaufman}

VESSEL NO.: 2003.08.1513b

NON-PLASTICS AND PASTE: shell

VESSEI FORM: Bottle

RIM AND LIP FORM: N/A

CORE COLOR: B (fired and cooled in a reducing environment)

INTERIOR SURFACE COLOR: dark gray

EXTERIOR SURFACE COLOR: dark gray

WALL THICKNESS (RIM, BODY, AND BASE IN MM): body, $3.2 \mathrm{~mm}$ 
INTERIOR SURFACE TREATMENT: none

EXTERIOR SURFACE TREATMENT: none

HEIGHT (IN CM): N/A

ORIFICE DIAMETER (IN CM): N/A

DIAMETER AT BOTTOM OF RIM OR NECK (IN CM): N/A

BASE DIAMETER (IN CM): N/A

ESTIMATED VOLUME (IN LITERS): N/A

DECORATION (INCLUDING MOTIF AND ELEMENTS WHEN APPARENT): The vessel body has at least seven sets of opposed incised lines that encircle the vessel.

PIGMENT USE AND LOCATION ON VESSEL: none

TYPE [IF KNOWN]: possible Keno Trailed

\section{SITE NAME OR SITE NUMBER: Sam Kaufman}

VESSEL NO.: 2003.08.1514

NON-PLASTICS AND PASTE: shell

VESSEL FORM: Jar

RIM AND IIIP FORM: everted rim and rounded lip

CORE COLOR: B (fired and cooled in a reducing environment)

INTERIOR SURFACE COLOR: dark grayish-brown

EXTERIOR SURFACE COLOR: dark grayish-brown

WALL THICKNESS (RIM, BODY, AND BASE IN MM): rim, $7.4 \mathrm{~mm}$; body, $6.2 \mathrm{~mm}$; base, $9.0 \mathrm{~mm}$

INTERIOR SURFACE TREATMENT: none

EXTERIOR SURFACE TREATMENT: nOne

HEIGHT (IN CM): N/A; rim height is $3.8 \mathrm{~cm}$

ORIFICE DIAMETER (IN CM): 20.0

DIAMETER AT BOTTOM OF RIM OR NECK (IN CM): 16.0

BASE DIAMETER (IN CM): 7.5

ESTIMATED VOLUME (IN LITERS): N/A

DECORATION (INCLUDING MOTIF AND FI.FMENTS WHEN APPARENT): There are appliqued nodes under the vessel lip, but the rim is otherwise plain.

PIGMENT USE AND LOCATION ON VESSEL: none

TYPE [IF KNOWN]: Unidentified utility ware 


\section{SITE NAME OR SITE NUMBER: Sam Kaufman}

VESSEL NO.: 2003.08.1872

NON-PLASTICS AND PASTE: shell

VESSEL FORM: Jar

RIM AND LIP FORM: everted rim and a rounded, exterior folded lip

CORE COI.OR: B (fired and cooled in a reducing environment)

INTERIOR SURFACE COLOR: dark grayish-brown

EXTERIOR SURFACE COLOR: dark grayish-brown

WALL THICKNESS (RIM, BODY, AND BASE IN MM): rim, $4.7 \mathrm{~mm}$; body, $5.6 \mathrm{~mm}$; base, $9.2 \mathrm{~mm}$

INTERIOR SURFACE TREATMENT: smoothed

EXTERIOR SURFACE TREATMENT: smoothed

HEIGHT (IN CM): 20.0

ORIFICE DIAMETER (IN CM): 20.0

DIAMETER AT BOTTOM OF RIM OR NECK (IN CM): 20.0

BASE DIAMETER (IN CM): 10.5

ESTIMATED VOLUME (IN LITERS): 3.6

DECORATION (INCLUDING MOTIF AND ELEMENTS WHEN APPARENT): The rim is decorated with three horizontal rows of neck banding.

PIGMENT USE AND LOCATION ON VESSEL: none

TYPE [IF KNOWN]: Nash Neck Banded

\section{SUMMARY AND SYNTHESIS}

During the winter of 196I-1962, Buddy Calvin Jones located and excavated eight burials along the cut bank of the Red River at the Sam Kaufman site (41RR16). The cemetery was located about $120 \mathrm{~m}$ west of the West Mound at the site. The burials were Caddo adults and one adolescent individual from the Sam Kaufman village that were placed in extended supine positions in the grave pits, and these pits were aligned mostly east-west, with the head facing west; in the case of three individuals in three different burials, their bodies were oriented east-west, but their head was turned to face in a southerly direction. Burial No. 2 had two individuals placed in it, one individual lying partially over the other (see Figure 3 ).

Ceramic vessels were placed as associated grave goods in all eight of the burials in the cemetery, with a range of two-eight vessels per burial (Table 1). the mean number of vessels is $5.0 \pm 1.5$ per burial. The only other grave goods were a number of bone tools, bison bone, deer bone, and a polished beaver tooth from Burial No. 4. The relatively mundane and redundant character of the associated grave goods from these burials suggests they are the burials of typical village residents, and were not part of the elite (i.e., religious and political leaders and their retainers) population who lived at the site and were buried in the East Mound (Perttula 2008a:Figure 6; Skinner et al. 1969) 
Table 1. Associated Grave Goods from Burials 1-8.

\begin{tabular}{|c|c|c|c|c|c|c|c|c|c|}
\hline $\begin{array}{l}\text { Associaled Grave } \\
\text { Goods }\end{array}$ & $\mathrm{B} 1$ & $\mathrm{~B} 2$ & B3 & B4 & B5 & B6 & B7 & B8 & $\mathrm{N}$ \\
\hline Ceramic Vessels & 8 & 6 & 5 & 4 & 4 & 4 & 2 & 7 & 40 \\
\hline Bone tools & - & - & - & 3 & - & - & - & - & 3 \\
\hline Bison bone & - & - & - & 1 & - & - & - & - & 1 \\
\hline Deer bone & - & - & - & 2 & - & - & - & - & 2 \\
\hline Beaver tonth & - & - & - & 1 & - & - & - & - & 1 \\
\hline Totals & 8 & 6 & 5 & 11 & 4 & 4 & 2 & 7 & 47 \\
\hline
\end{tabular}

The constellation of ceramic vesscl types in this collection from the Sam Kaufman site, most notably the many shell-tempered ceramic types, indicates that the eight burial features excavated by Buddy Calvin Jones date to the latter part of the Late Caddo McCurtain phase, after ca. A.D. 1450/1500 (Perino 1994:28: Perttula 1992:Table 11, 2008a:377 and Table 1), and extending to between ca. A.D. 1650/1700. This age range is consistent with the occurrence of Hudson Engraved and Keno Trailed from a number of the burials, and the hubcap-shaped variety of Simms Engraved in Burial No. 2. Other ceramic types-Avery Engraved, Emory Punctated-Incised, McKinney Plain, and Nash Neck Banded - tend to occur in both the early and late parts of the McCurtain phase.

Table 2. Ceramic Types by Burial Features and Unprovenienced Contexts.

\begin{tabular}{|c|c|c|c|c|c|c|c|c|c|}
\hline Ceramic Type & $\mathrm{B} 1$ & $\mathrm{~B} 2$ & B3 & B4 & B5 & B6 & B7 & B8 & UNK \\
\hline \multicolumn{10}{|l|}{ Grog-tempered } \\
\hline $\begin{array}{l}\text { Maxcy Noded } \\
\text { Redware }\end{array}$ & - & - & - & - & - & - & - & - & $\mathrm{x}$ \\
\hline \multicolumn{10}{|l|}{ Shell-tempered } \\
\hline Avery Engraved & - & $x$ & $\mathrm{x}$ & - & - & - & - & $\mathrm{x}$ & $\mathrm{x}$ \\
\hline $\begin{array}{l}\text { Emory Punctated- } \\
\text { Incised }\end{array}$ & - & - & - & - & - & - & - & $\mathrm{x}$ & $x$ \\
\hline Hudson Engraved & - & $\mathrm{x}$ & $\mathrm{x}$ & - & - & $x$ & $x$ & $\mathrm{x}$ & $x$ \\
\hline Keno Trailed & $x$ & - & - & $x$ & - & $x$ & - & - & $x$ \\
\hline McKinney Plain & - & - & - & - & - & - & - & - & $\mathrm{x}$ \\
\hline Nash Neck Banded & $x$ & - & $x$ & $x$ & - & $\mathrm{x}$ & $\mathrm{x}$ & - & $x$ \\
\hline Simms Engraved & $x$ & $x$ & - & $x$ & - & - & $\mathrm{x}$ & - & - \\
\hline
\end{tabular}

$\mathrm{x}=$ present; $\mathrm{UNK}=$ unknown 
The grog-tempered Maxey Noded Redware bottle from an unknown provenience in the Sam Kaufman collection is very likely not associated with any of the post-ca. A.D. 1450/1500 Late Caddo burials in the cemetery. This distinctive ceramic type (see Suhm and Jelks 1962:Plate 51) is typically found in Middle Caddo period contexts along the middle Red River, in this case in Mound Prairic phase occupations dating from ca. A.D. 1100-1300 (Perttula 2008a:Table 1).

\section{ACKNOWLEDGEMENTS}

We appreciate the opportunity provided by the Gregg County Historical Muscum to document the Sam Kaufman collection in its holdings. Patti Haskins was particularly helpful with locating the collections and notes for our study. Lance Trask prepared the maps for this article, and Bo Nelson took all of the photographs.

\section{REFERENCES CITED}

Banks, L. D. and N. T. Banks

2002 Last Twentieth Century Archeological Investigations at the Arnold Roitsch Site (4IRRI6), Red River County, Texas. Larry D. Banks, Detroit, Texas.

Bruseth, J. E.

1998 The Development of Caddoan Polities along the Middle Red River Valley of Eastern Texas and Oklahoma. In The Native History of the Caddo: Their Place in Southeastern Archeology and Ethnohistory, edited by T. K. Perttula and J. E. Bruseth, pp. 47-68. Studies in Archeology 30. Texas Archeological Research Laboratory, The University of Texas at Austin.

Bruseth, J. E. and T. K. Perttula

19911991 TAS Field School, The Sam Kaufman Site (41RR16), Red River County, Texas. Texas Archeology 35(2):3, 13-14, 19.

Butler, B. H.

1969 Analysis of the human skeletal remains. In Archaeological Investigations at the Sam Kaufman Site, Red River County, Texas, edited by S. A. Skinner, R. K. Harris, and K. M. Anderson, pp. 115-136. Contributions in Anthropology No. 5. Department of Anthropology, Southern Methodist University, Dallas.

Derrick, S. M., G. R. Colby, and D. G. Steele

2008 Analysis of Human Remains from the Arnold Roitsch Site (41RR 16). In "The Archeology of the Roitsch Site (41RR16), an Early to Historic Caddo Period Village on the Red River in Northeast Texas," by T. K. Pertlula. In Collected Papers from Past Texas Archeological Society Summer Field Schools, edited by T. K. Perttula, pp. 413-432. Special Publication No. 5. Texas Archeological Society, San Antonio.

Gonzalez, B.

2005 Caddo Tribal Religious Burial Ceremonies beyond Archeology. In A Rediscovering of Caddo Heritage: The W. T. Scott Collection at the American Museum of Natural History and Other Caddo Collections from Arkansas and Louisiana, by B. Gonzalez, R. L. Cast, T. K. Pertlula, and B. Nelson, pp. 55-59. Historic Preservation Program, Caddo Nation of Oklahoma, Binger.

Hampton, H. and G. Moore

1936 A Burial Site in Northcastern Red River County. Central Texas Archeologist 2:64-68. 
Harris, R. K.

1951 An Unusual Stone Pipe from the Sam Kaufman Site. The Record 10(2):6. Dallas Archeological Society, Dallas.

1953 The Sam Kaufman Site, Red River County, Texas. Bulletin of the Texas Archeological Society 24:43-68.

Harris, R. K., and L. Wilson

1956 Burial 17, The Sam Kaufman Site (19B3-2). The Record 14(4):17-22. Dallas Archeological Society, Dallas.

Harris, R. K., Mr. J. Perkins, and Mrs. J. Perkins

1954 Burials 12,13, 14, and 15, The Sam Kaufman Site 19B32. The Record 13(1):2-8. Dallas Archeological Society, Dallas.

Kenmotsu, N. A.

2001 Salt Well Slough (41RR204). Bulletin of the Texas Archeological Society 72:213-222.

2006 Investigations at the Salt Well Slough Site (41RR204), a Salt Making Site in Red River County, Texas. Archeological Reports Series. No. 4. Texas Historical Commission, Austin.

Loveland, C. J.

1980 The Skeletal Biology of the Caddo Indians of the Kaufman-Williams Site, Red River County, Texas. Ph.D. dissertation, Department of Anthropology, University of Tennessee, Knoxville.

1994 Vertebral Anomalies and Degenerative Lesions in the Caddoan Skeletal Population, KaufmanWilliams Site, Red River County, Texas. Bulletin of the Texas Archeological Socicty 65:161-181.

Loveland, C. J., and W. M. Bass

1983a Human Skeletal Remains from the Williams Site. In Archaeological Research at the Bob Williams Site (41RR16), Red River County, Texas, by G. Pcrino, pp. 85-144. Museum of the Red River, Idabel.

1983b Cranial Studies of the Caddo Indians from the Kaufman-Williams Site. In Southeastern Natives and Their Pasts, edited by D. G. Wyckoff and J. L. Hofman, pp. 241-257. Studies in Oklahoma's Past No. 11. Oklahoma Archeological Survey, Norman.

Loveland, C. J., J. B. Gregg, and W. M. Bass

1984 Ancient Osteopathology from the Caddoan Burials at the Kaufman-Williams Site, Texas. Plains Anthropologist 30(107):29-43.

Perino, G.

1983 Archaeological Research at the Bob Williams Site (41 RR16), Red River County, Texas. Museurn of the Red River, Idabel.

1994 Archaeological Research at the Rowland Clark Site (41RR77), Red River County, Texas. Journal of Northeast Texas Archaeology 4:3-42.

Perkins, J. L.

1955 Burial 16 at the Sam Kaufman Site 19B3-2. The Record 14(1):2-6. Dallas Archeological Society, Dallas.

Perttula, T. K.

1992 "The Caddo Nation": Archaeological and Ethnohistoric Perspectives. University of Texas Press, Austin.

2006 A Study of the Buddy Calvin Jones Collection from Northeast Texas Caddo Sites, Special Publication No. 6. Friends of Northeast Texas Archaeology, Austin and Pittsburg. 
2008a The Archeology of the Roitsch Site (41RR16), an Early to Historic Caddo Period Village on the Red River in Northcast Texas. In Collected Papers from Past Texas Archeological Society Surmer Field Schools, edited by T. K. Perttula, pp. 313-628. Special Publication No. 5. Texas Archeological Society, San Antonio.

2008b Archeological Survey of the Roitsch Farm and Adjoining Lands, 1991 and 1992 Texas Archeological Society Field School, Red River County, Texas. In Collected Papers from Past Texas Archeological Society Summer Field Schools, edited by T. K. Perttula, pp. 173-312. Special Publication No. 5. Texas Archeological Sociely, San Antonio.

Perttula, T. K. (editor)

2005 Archeological Investigations at the Pilgrim's Pride Site (41CP304), a Titus Phase Community in the Big Cypress Creek Basin, Camp County, Texas. 2 Vols. Report of Investigations No. 30. Archeological \& Environmental Consultants, LLC, Austin.

Perttula, T. K., J. E. Bruseth, N. A. Kenmotsu, D. J. Prikryl, W. A Martin, L. Banks, J. Smith, N. G. Reese, and S. A. Iruegas

2001 Archeological Investigations on the Red River and Tributaries: Summary of the Findings of the 1991 and 1992 Tcxas Archeological Society Field School in Red River and Lamar Counties, Texas. Bulletin of the Texas Archeological Society 72:165-250.

Perttula, T. K., M. Tate, H. Neff, J. W. Cogswell, M. D. Glascock, E. Skokan, S. Mulholland, R. Rogers, and B. Nelson

1998 Analysis of the Titus Phase Morruary Assemblage at the Mockingbird Site "Kuhbakayammaahin" (4ITT550). Document No. 970849. Espey, Huston \& Associates, Inc., Austin.

Perttula, T. K., M. Walters, S. Marceaux, and B. Nelson

2009 Caddo Pottery Vessels and Pipes from Sites in the Middle and Upper Sabine and Upper Neches River Basins, Smith and Wood Counties, Texas. Special Publication No. 7. Friends of Northeast Texas Archaeology, Austin and Pittsburg.

Prikryl, D. J.

2008 The 1991 and 1992 Texas Archeological Society Field School Excavations at the Fasken Site (41RR 14), Red River County, Texas. In Collected Papers from Past Texas Archeological Society Summer Field Schools, edited by T. K. Perttula, pp. 125-171. Special Publication No. 5. Texas Archeological Society, San Antonio.

Reese, N. G.

2001 Archeological and Archival Investigations of the Jonesborough Site (4IRR15), Red River County. Texas. Archeological Reports Series, No. 2. Texas Historical Commission, Austin.

Skinner, S. A., R. K. Harris, and K. M. Anderson (editors)

1969 Archaeological Investigations at the Sam Kaufman Site, Red River County, Texas. Contributions in Anthropology No. 5. Department of Anthropology, Southern Methodist University, Dallas. 